THE LONG ARM OF PROSPECTIVE CHILDHOOD INCOME FOR MATURE ADULT HEALTH IN THE U.S.*

\author{
David Brady (ORCID 0000-0002-4059-3272) \\ University of California, Riverside \& WZB Berlin Social Science Center \\ Christian Guerra \\ University of California, Riverside \\ Ulrich Kohler \\ University of Potsdam \\ Bruce Link \\ University of California, Riverside
}

December 12, 2021

Word Count: 9258 (excluding title, abstract, tables, figures \& appendices)

* Direct correspondence to David Brady, School of Public Policy, University of California, INTS 4133, 900 University Ave., Riverside, CA 92521; email: dbrady@ucr.edu. 


\title{
THE LONG ARM OF PROSPECTIVE CHILDHOOD INCOME FOR MATURE ADULT HEALTH IN THE U.S.
}

\begin{abstract}
Pioneering scholarship links retrospective childhood conditions to mature adult health. We distinctively provide critical evidence with prospective state-of-the-art measures of parent income observed multiple times during childhood in the 1970s-1990s. Using the Panel Study of Income Dynamics, we analyze six health outcomes (self-rated health, heart attack, stroke, lifethreatening chronic conditions, non-life-threatening chronic conditions, and psychological distress) among 40-65 year olds $(\mathrm{N}=3,813-3,944)$. Parent relative income rank has statistically and substantively significant relationships with five of six outcomes. The relationships with heart attack, stroke and life threatening chronic conditions are particularly strong. Parent income rank performs slightly better than alternative prospective and retrospective measures. At the same time, we provide novel validation on which retrospective measures (i.e. father's education) perform almost as well as prospective measures. Further, we inform several perennial debates about how relative versus absolute income and other measures of socio-economic status and social class influence health.
\end{abstract}

Running Head: Childhood Income and Mature Adult Health

Keywords: income, life course, social class, health disparities 
Pioneering scholarship demonstrates a relationship between retrospective childhood conditions and mature adult health. Mounting evidence of a "long arm of childhood" shows that early life conditions have long-term consequences for health much later in life (e.g. Ferraro et al. 2015; Hayward and Gorman 2004; Lee and Ryff 2019; Montez and Hayward 2014; Turner et al. 2016; Warner and Hayward 2006; Yang et al. 2020). This literature informs enduring theoretical debates on pervasive socio-economic disparities in health (Case et al. 2002; Elo 2009; Marmot 2005). These studies also advance a core theme of life course research that childhood conditions place people on trajectories that shape life chances and health (Melchior et al. 2007; Montez et al. 2016; Poulton et al. 2002; Wilson et al. 2007). Moreover, these studies illustrate how childhood conditions are fundamental causes of health - operating as a distal cause that puts people at risk of risks for adverse health (Clouston and Link 2021; Link and Phelan 1995).

This literature has been innovative for at least two additional reasons. First, rather than linking childhood economic resources to proximate young adult health (e.g. Duncan et al. 2010; Duncan et al. 2012; Lillard et al. 2015; Melchior et al. 2007; Poulton et al. 2002; Ziol-Guest et al. 2009), these studies show much longer term consequences for older adults. Second, rather than the well-established connection between adult economic resources and adult health (e.g. Adler et al. 1994; Avendano and Glymour 2008; Chetty et al. 2016; Dupre et al. 2012), these studies show that some of the causal origins are from much earlier in life. In turn, childhood economic conditions can now serve as an early warning signal for health problems in mature adulthood. Moreover, public policy interventions can be more effectively targeted if we can gain an understanding of precisely how childhood economic resources matter.

Despite these contributions, the literature has been constrained by two key limitations. First, much of the literature relies on retrospective self-reports of childhood socioeconomic 
conditions from older adult respondents. Second, relatedly, the measurement of childhood economic resources could be improved.

The present study explicitly addresses these limitations while deepening understanding of the long arm of childhood. We analyze the Panel Study of Income Dynamics (PSID), which provides a large, nationally representative panel observed multiple years during both childhood and mature adulthood. Uniquely, we incorporate the Cross-National Equivalent File (CNEF), which is a supplement of the PSID that provides enhanced state-of-the-art measures of income. This enables us to combine better measures of income observed multiple times during a respondent's childhood with long term follow-up for multiple health outcomes during mature adulthood. Compared to prior PSID research, we exploit more recent waves to observe health later in respondents' lives and to include a larger sample of children from the 1980s and 1990s who have now aged into mature adulthood. Moreover, we incorporate a wide variety of health outcomes. By doing so, we provide an even more robust test of the influence of childhood income. This approach provides critical and novel evidence for the long arm of childhood with prospective childhood income data. In the process, we inform several perennial debates about how relative versus absolute economic resources and social class influence health.

\section{PAST RESEARCH}

As previewed above, many link retrospective measures of childhood to mature adult health. For instance, Hayward and Gorman (2004) find that childhood economic disadvantage predicts mortality among 45-75 year olds (also Montez and Hayward 2014; Warner and Hayward 2006). Those authors use retrospective questions from National Longitudinal Survey of Older Men when respondents were 45-59 years old about family circumstances when 
respondents were aged 15. Specifically, they examine retrospective measures of parents' education, occupation, family structure, and nativity.

Several studies analyze retrospective self-reports of childhood among 25-74 year olds in the National Survey of Midlife Development in the US (MIDUS). These studies integrate various self-reported indicators about childhood such as parental unemployment, housing conditions, and subjective economic standing. For instance, Lee and Ryff (2019) use latent class analysis to scale adults' reports of multiple adverse childhood experiences. Ferraro and colleagues (2015) show childhood economic disadvantage significantly increases disease and undermines healthy aging among 25-74 year olds (also Schafer and Ferraro 2011; Schafer et al. 2011). Morton and colleagues (2014) show that recollections of having received welfare or being financially worse off predicts acute myocardial infarction.

Others use retrospective self-reports of childhood in the Health and Retirement Study (HRS) (Morton and Ferraro 2020). Again, composite scales have been constructed based on various indicators (e.g. whether father had a white/blue collar job; the family was "pretty welloff, about average, or poor;" financial difficulty caused the family to move; etc) (e.g. HamilLuker and O'Rand 2007). For instance, Luo and Waite (2005) find that retrospective adult selfreports of childhood conditions predict self-rated health, functional limitations, chronic conditions, and depression among 51-75 year olds.

A smaller literature uses prospective administrative or survey data when respondents were both children and mature adults (e.g. Gilman et al. 2002; Kauhanen et al. 2006; Martikainen et al. 2020; Moorman et al. 2019; Link et al. 2017; Yang et al. 2020). For example, the 1958 British birth cohort National Child Development Study includes data on respondents aged 11-16 (e.g. mother's employment, father's occupation, subjectively perceived financial 
situation, self-reported household amenities) (e.g. Jefferis et al. 2002). The Medical Research Council National Survey of Health and Development has followed respondents from birth in 1946 in Great Britain. Using this data, Kuh and colleagues (2002) predict mortality ages 26-54 based on father's manual vs. non-manual social class measured at age 4 , and subjective evaluations and interviewer scores of housing and living conditions. Using the California-based Child Health and Development Study, Link and colleagues (2017) show that a composite of prospective maternal education, paternal occupation and family income in childhood is associated with self-rated health at age 50 .

Others use the PSID to examine how children's economic resources in the 1960s-1970s affect adult health (e.g. Duncan et al. 2012; Laditka and Laditka 2012; Vartanian and House 2010; Zheng et al. 2020; Ziol-Guest et al. 2009). For instance, Shuey and Wilson (2014) analyze how trajectories of official U.S. poverty beginning with ages 0-8 in 1968 influence trajectories of self-rated health at ages $42-49$ in 1999-2009 (also Wilson et al. 2007). Using the PSID through 2003 and 2007, Johnson and Schoeni (2011) examine how family income and poverty at ages 13-16 in 1968-1975 influence self-rated health, asthma, hypertension, diabetes, stroke, heart attack, and heart disease at ages 39-52 or 39-56.

\section{IMPROVING THE MEASUREMENT OF CHILDHOOD ECONOMIC RESOURCES}

The prior literature has made substantial contributions. However, it has been constrained by two key limitations that our study distinctively addresses: Most have relied on (a) on retrospective data; and/or (b) imprecise measures of childhood economic resources. Even among those using prospective data, the measurement of economic resources could be improved and there is a paucity of nationally representative samples of the U.S. with its well-known 
heterogeneities. Therefore, it would be valuable to have strong evidence from prospective nationally representative data (Elo 2009).

Previous research demonstrates that much can be learned from retrospective reports. However, retrospective reports of childhood conditions several decades later are prone to recall bias and are unlikely to be as strong as prospective measures (Song and Mare 2014). For instance, adults' retrospective reports are often inaccurate of whether their family was ever temporarily on welfare when they were young (Robins et al. 1985). Such error is common even with major adverse experiences in childhood (Hardt and Rutter 2004). Plausibly, sicker and distressed mature adults may reflect their poor health back into their memories of childhood. Poor health could undermine memories or even retrospectively construct negative narratives of childhood to account for present health problems (Schacter 2001). Such biases could inflate the relationship between childhood economic resources and mature adult health. Further, such biases could be exacerbated when childhood conditions are measured subjectively (e.g. reports that one's family was "poor" or "well off"). By contrast, prospective measures of childhood living conditions better predict adult mortality than retrospective questionnaires about childhood economic standing (Kauhanen et al. 2006). Given all this, our first contribution is to assess prospective measures and, in the process, compare prospective and retrospective measures.

Our second contribution is to improve the measurement of economic resources. In the long arm literature, many construct composite scales of general childhood conditions or disadvantage. Even in the few prospective studies - largely because economic resources were often not as well-measured in the 1940s-1970s when the data was originally collected childhood economic resources are often fairly crudely measured. Because composite scales incorporate many different indicators of varying quality, it remains uncertain which specific 
aspects of childhood economic resources are most salient. Moreover, if childhood disadvantage is a composite of many indicators, intervening on any one or a few indicators will not necessarily improve subsequent health if other indicators in a composite are what really matters. Also, some widely used indicators, such as father's occupation, would be extremely difficult to intervene on. By contrast, childhood income has the advantage of being more precise and concrete conceptually, and provides a plausible basis for public health interventions.

For these reasons, we propose the long arm literature can benefit from advances in international income research. Following the United Nations' (2011) "Canberra Group," a consensus emerged on the criteria for optimal income measurement (Brady et al. 2020; Brady et al. 2018; Brady and Parolin 2020; Daly et al. 2002; Duncan et al. 2001; Rainwater and Smeeding 2004; Smeeding and Weinberg 2003). Measures of income should: (1) include all sources from all household (HH) members; (2) incorporate taxes and transfers (i.e. be "post-fisc"); (3) be equivalized for HH size; and ideally, (4) observed over multiple time points.

These criteria emphasize that individuals reside in HHs and have "disposable" income after taxes and transfers and this measure best gauges economic resources. Living in HH's and accessing transfers are principal ways individuals smooth their incomes, manage volatility and maximize well-being (Bartfield et al. 2015; Brady et al. 2018; Gundersen and Ziliak 2003). For example, Hoynes and colleagues (2016) show that the Supplemental Nutritional Assistance Program (SNAP) improves children's well-being and has lasting benefits into adulthood. As well, tax credits and transfers reduce poverty and inequality (Brady and Parolin 2020; Rainwater and Smeeding 2005). Given the volatility of income, the reliability of income measurement increases significantly with multiple observations (Brady et al. 2018; Fox et al. 2016; Mazumder 2016). Multiple observations also reveal much greater intergenerational transmission of income 
and, hence, lower mobility (Brady et al. 2020; Fox et al. 2016; Mazumder 2016). Further, multiple observations of childhood income better predict subsequent health, well-being and life chances than single observations (Blau 1999; Brady et al. 2020; McLeod and Shanahan 1996).

Such measures of post-fisc HH equivalized income better predict adult life chances and better explain black-white inequalities in adult life chances (Brady et al. 2020). Also, Brady and colleagues (2018) demonstrate that this measure in one randomly chosen year explains about half of the variation in lifetime average "permanent" income. They also show that multiple time points of this measure can explain most of the variation in permanent income. Recall several studies in the long arm literature rely on measures of parents' occupation or subjective social class. Brady and colleagues (2018) demonstrate that post-fisc equivalized income predicts permanent income better than one-, two- and three-digit occupation and the widely used EriksonGoldthorpe measure of social class.

Prior studies in the long arm literature have not incorporated prospective post-fisc equivalized income. Even among prior PSID studies, studies have not used these optimal income measures (Daly et al. 2002). For instance, although Duncan and colleagues (2010) use the PSID's "high quality edited measure of annual total family income," their measure only includes earnings and investment income and cash transfers like TANF. By contrast, we incorporate taxes, tax credits and near-cash transfers like SNAP. Innovating beyond such research with the PSID, we also equivalize for $\mathrm{HH}$ size.

Our third contribution is to inform several perennial debates about how best to measure and model how economic resources and social class shape health (Elo 2009). Importantly, prospective measures make it is far more feasible to contribute to these debates than analyses based solely on composite indices and retrospective measures. 
First, there has long been a debate between relative and absolute income (Elo 2009; Fox et al. 2016). Relative income locates one relationally and hierarchically within a distribution of a time and place. Income is a positional good and a basis for status compared to others in a cultural and historical context (Marmot 2005). The living standards in one's context shape what gets defined as a "need," and therefore having sufficient resources to meet one's needs is always relative (Rainwater and Smeeding 2004). As incomes rise and with economic development, health will not necessarily improve if one's standing amongst others declines or is stagnant (Avendano 2012; Easterlin et al. 2010). By contrast, absolute income measures resources independent of time and place. Health and well-being should mechanically improve as absolute incomes increase (Stevenson and Wolfers 2013) and with economic development (Deaton 2010). If absolute income is more important than relative income, then health and well-being depend on one's fixed material resources regardless of others' material resources in a community or society (Ladin et al. 2010; Veenhoven 1991).

Second, debate has long existed about the salience of income compared to other measures of socio-economic status or social class, such as occupation and education (Brady et al. 2020), and how those different measures influence health (e.g. Daly et al. 2002; Elo 2009; Geyer et al. 2006; Herd et al. 2007; Schnittker 2004). Third, if childhood income influences mature adult health, it would be useful to investigate the optimal functional form (Elo 2009). For example, using the PSID, Duncan and colleagues (2010) show there are differential impacts of increments of low versus high childhood income for outcomes in respondents' 30s. As a result, we also test if the relationship between childhood income and mature adult health is nonlinear.

\section{DATA AND METHODS}


We used the Panel Study of Income Dynamics (PSID 2013). The PSID is a longitudinal, nationally representative study fielded annually 1968-1997 and biannually since. We also used the Cross-National Equivalent File (CNEF), which is a supplement to the PSID (Frick et al. 2007). The CNEF distinctively provides the higher quality income measures incorporating taxes, tax credits, and transfers (Brady et al. 2020; VanHeuvelen and Brady Forthcoming).

The sample was based on individuals who were children ( $0-17$ years) in households interviewed 1970-1996 and subsequently followed until mature adulthood. To be included, we required that the respondent have valid income data at least twice during childhood and had valid health data at $40+$ years old. The timing for our study was enhanced by the fact that a large sample of PSID children in the 1980s-1990s had recently aged into mature adulthood. We selected the oldest/most recent observation for each respondent through the 2019 wave. ${ }^{1}$ Thus, we used observations from the 1999-2019 waves even though most came from the 2019 wave.

Across outcomes, sample sizes ranged from 3,813-3,944. Appendix I confirms the results and conclusions were robust if we confined the analyses to a common $\mathrm{N}$ non-missing on all outcomes. The descriptive statistics and a correlation matrix are displayed in Appendix A. The mean age was 52 years old. About $10 \%$ of the sample was $62-65$ years old, about $25 \%$ was 58 65 , and only about $25 \%$ was $40-46$ years old. In sensitivity analyses below, we reported analyses based on samples of $30+$ and $50+$ year olds.

\section{Adult Health Outcomes}

Recent PSID waves contained a variety of mature adult health outcomes. To the best of our knowledge, past studies have not used the most recent waves and/or included the full variety of health outcomes. One advantage of our approach is that we used both subjective assessments of well-being and objective reports of physician diagnosis. While physician diagnosis requires 
access to healthcare and respondent recall, subjective assessments are also imperfect. We were most interested in robust relationships across both sets of outcomes.

We note that the health outcomes are self-reports for heads of households, but proxy reports for spouses. Proxy reporting was a limitation and Appendix F showed results dropping proxy reports. Also, some readers may be concerned with including multiple adults per household so Appendix F only included one adult per household (i.e. heads). Fortunately, dropping proxy reports and sampling only heads did not change our conclusions. So, we included both self- and proxy-reports in the main analyses.

For general health status, we used the standard 5-point self-rated health item (Benyamini and Idler 1999; Brady et al. 2020; Johnson and Schoeni 2011; Schnittker and Bacak 2014): Selfrated health $(1=$ poor, $2=$ fair, $3=$ good, $4=$ very good, $5=$ excellent). The mean self-rated health was 3.3.

We measured if the respondent ever reported that a doctor had diagnosed that $\mathrm{s} / \mathrm{he}$ had experienced each of two major acute health events: heart attack or stroke (Brady et al. 2020). $11 \%$ of the sample has had a heart attack and $5 \%$ has experienced a stroke. ${ }^{2}$

The PSID provided a battery of self-reports of whether a doctor has diagnosed the respondent as having any chronic conditions. We divided seven chronic conditions into life threatening and non-life threatening. ${ }^{3}$ Life threatening included high blood pressure/heart disease, cancer, diabetes, and lung disease. Non-life threatening included asthma, arthritis, and "other chronic" conditions. In the sample, $46 \%$ had at least one life-threatening chronic condition and $41 \%$ had a non-life threatening chronic condition.

Finally, Psychological distress was scored 0-24 using Kessler and colleagues' (2002) K-6 non-specific scale (Brady et al. 2020; Duncan et al. 2010). The mean was 3.4. 


\section{Childhood Economic Resources}

To optimize measurement of parent income, we used the CNEF to measure post-fisc equivalized household income. "Post-fisc" includes cash and near cash transfers (e.g. SNAP), subtracts taxes (with the National Bureau of Economic Research's "TAXSIM" Model), and adds tax credits (e.g. the Earned Income Tax Credit). Our measure includes all household members. We equivalized for household size by dividing by the square root of $\mathrm{HH}$ members (Brady et al. 2018; Rainwater and Smeeding 2004).

We averaged this measure over a respondent's entire observed childhood (i.e. ages 0-17). Recall, we required respondents have at least two income observations. In our sample, the mean respondent had about 11 observations. More than $95 \%$ of the sample had $3+$ observations.

Our principal measure is parent income rank. We used the PSID-CNEF to calculate relative rank as percentiles in each year. Fortunately, the PSID-CNEF had a large sample (typically $>20,000$ ) in each year and the weights made the dataset nationally representative. For each respondent, we then averaged their relative rank percentiles over childhood (i.e. ages 0-17).

In subsequent Models, we included alternative measures of childhood economic resources. First, we measured parent absolute income (in inflation-adjusted 2021 dollars). Alternative analyses transformed both relative rank and absolute income into logs and polynomials. Second, we estimated the Models while adding 2-digit occupations. Third, we included two sets of retrospective childhood measures available in the PSID. Father's educational attainment was measured categorically as father has college degree and father has high school degree (reference=less than high school degree). Subjective retrospective family economic standing was measured with binary variables for parents were poor and parents were well off $($ reference $=$ neither poor nor well-off $)$. 


\section{Control Variables}

In addition to prospective parent income, we included four other prospective measures of family background observed during childhood. ${ }^{4}$ These measures were also averaged over the entire set of observations during childhood (Brady et al. 2020). Rather than simply adopting the PSID identified head, we defined the household lead earner as the adult with the highest labor market earnings in the household in a given year (Brady et al. 2018). Ties were broken by age (and chosen randomly if age is tied). Across the respondent's observed childhood, we used the lead to calculate the average lead age in years and average lead education in years of schooling. We also adjusted for sibship size, which is the average number of other children in the household during childhood. Finally, we included parent single motherhood as the proportion of years in a single mother household during childhood.

The average respondent grew up with a parent with 12 years of schooling and a lead average age of 39 years old during their childhood. The mean respondent had a sibship size of 1.8. On average, about $14 \%$ of years during childhood were in single mother households.

In the wave when health outcomes were measured, we adjusted for the age of the respondent in years (mean 52). We also included mutually exclusive binary measures of whether respondents are Black, Latino or Other Race (reference=white). Approximately $14 \%, .1 \%$ and $4 \%$ of the sample are black, Latino, and other race individuals. As is well-documented for longterm PSID samples, the PSID only effectively samples black and white individuals (Brady et al. 2020). Finally, we controlled for a binary indicator for Female (51\%).

\section{Analysis}

The analyses were regression Models and the unit of analysis was the individual. The Models predicted recent health outcomes (observed at 40+ years) as a function of income and 
other variables during childhood (observed 0-17 years) and a few contemporaneous controls (observed at 40+ years). All Models were linear. This included the binary outcomes, which were linear probability Models. In analyses available upon request, we estimated logit Models and the results led to the same conclusions. Because we used the oldest/most recent observation for each respondent and those observations can come from the 1999-2019 waves, our analyses included fixed effects for the wave when the outcome was observed (not shown). The wave fixed effects applied to the observation of mature adult health (not childhood) and netted out any unusual qualities of any given year. Because households included multiple mature adult respondents and multiple adults who grew up in the same households, we used robust standard errors clustered at the original PSID household-level.

\section{RESULTS}

Table 1 shows the main Models for the six outcomes. The Models include all controls and wave fixed effects (not shown). The tables report standardized coefficients (stdB's) for continuous outcomes and X-standardized coefficients (xstdB's) for binary outcomes. ${ }^{5}$

\section{[ TABLE 1 ABOUT HERE ]}

Parent income rank has a statistically significant relationship with five of six outcomes: self-rated health, heart attack, stroke, life-threatening chronic condition, and psychological distress. Parent income rank does not significantly predict non-life threatening chronic conditions. Overall, it appears that parent income rank is more strongly associated with the most serious health outcomes, including life threatening chronic conditions and acute health events.

Parent income rank has similar coefficients for the continuous outcomes self-rated health and psychological distress. For a standard deviation increase in parent income rank (i.e. 24 
percentage points, see Appendix A), self-rated health is expected to be about .1 standard deviation higher and psychological distress is about .09 standard deviations lower.

Compared to a sample mean of $46 \%$, a standard deviation increase in parent income rank is expected to reduce the probability of a life threatening chronic condition by about 4.8 percentage points. Thus, a standard deviation higher parent income rank translates to about a $10 \%$ reduction in the probability of a life threatening chronic condition.

Based on a sample mean of about $11 \%$, a standard deviation increase in parent income rank is expected to reduce the probability of a heart attack by about 2.2 percentage points. This translates to roughly a $20 \%$ reduction in the probability of a heart attack. Relative to a sample mean of about $5 \%$, a standard deviation increase in parent income rank is expected to reduce the probability of a stroke by about 2.1 percentage points. Thus, a standard deviation higher parent income rank translates to about a $40 \%$ reduction in the probability of a stroke. ${ }^{6}$

Several controls are associated with mature adult health. For instance, age has a linear worsening relationship with all six health outcomes. Recall, the sample is aged 40-65, and in analyses available upon request, there is no evidence of a nonlinear relationship between these outcomes and age. Notably, the stdB's for parent income rank rival in magnitude those for age for several outcomes. For instance, a standard deviation increase in parent income rank (i.e. 24 percentage points) has a stdB larger similar to a standard deviation increase in age (i.e. 7.3 years, see Appendix A) for self-rated health, stroke, and psychological distress. Parent's education also significantly predicts several outcomes. The other parent characteristics (age, sibship size, and single motherhood) are not significantly associated with mature adult health outcomes net of the other variables in these Models. Again, we acknowledge parent's income is posttreatment control to these parent characteristics (i.e. their causal paths are likely blocked). ${ }^{7}$ 
After the main Models in Table 1, we now compare alternative prospective and retrospective measures for childhood economic resources. Because we estimated a large quantity of Models, we summarize the remaining Models using Figures. To be clear, these alternative Models are still important and we display the key coefficients in appendices. To summarize the results across these appendices, Figure 1 summarizes the key coefficients for parent income and Figure 2 summarizes model fit across Models.

On one hand, we do not find large differences across measures and Models. Figure 1 shows the confidence intervals for the parent income coefficients overlap. Figure 2 also reveals the model fit is mostly similar across Models. Hence, the main conclusion is that the results are robust. This should augment confidence in our prospective evidence for the long arm of childhood.

\section{[ FIGURE 1 ABOUT HERE ]}

\section{[ FIGURE 2 ABOUT HERE ]}

On the other hand, the Models with parent relative income rank are equally as or slightly more preferred than alternative approaches. Hence, prospective relative income rank is slightly more robustly statistically and substantively significant and explains slightly more of the variance in mature adult health than alternative approaches.

Appendix B shows that parent absolute income yields results consistent with the results for parent relative income rank. As Figure 1 shows, the confidence intervals for the coefficients overlap. The model fits are also similar. However, for every outcome, the coefficient for parent relative income rank is larger than the coefficient for parent absolute income. Compared to parent absolute income, parent relative income rank's coefficient is about $11 \%$ larger for selfrated health, 47\% larger for heart attack, 50\% larger for stroke, 55\% larger for life-threatening 
chronic condition, and 52\% larger for psychological distress. Unlike parent relative income rank, parent absolute income is not statistically significant for heart attack. Thus, relative income rank appears to slightly better predict mature adult health than absolute income.

Appendix B also shows that adding 2-digit occupation categories in the Models does not meaningfully improve understanding of how parent economic resources affect mature adult health (coefficients for occupations not shown). Figure 2 shows the adjusted R-squared does not improve meaningfully with the addition of a large quantity of occupation indicator variables. This is partly because the sample size drops considerably as parent occupation was missing throughout some respondents' childhoods. Still, Figure 1 shows the coefficients for parent income rank are similar even when adjusting for 2-digit occupation.

Appendix C compares Models including two sets of retrospective measures. We first include all five prospective measures (parent income rank, lead education and age, sibship size, and parent single motherhood) and each set of retrospective measures in the same Model. We then omit the prospective measures and feature each set of retrospective measures by themselves. Whenever we include retrospective measures, the Ns are lower than if we use prospective measures alone. However, Appendix C also shows similar results for prospective measures when we confine the $\mathrm{N}$ to those non-missing for retrospective measures. ${ }^{8}$

Figures 1-2 and Appendix C reveal five general patterns. First, Models combining prospective and retrospective measures do not really improve fit over Models featuring prospective measures alone. Second, Models featuring only prospective measures tend to fit as well as or slightly better than Models featuring only retrospective measures. Third, it is plausible that prospective parent income is endogenous to these particular retrospective measures. ${ }^{9}$ For instance, father's educational attainment likely causes parent income rank. Consistent with this, 
the retrospective measures have larger and more significant coefficients when prospective parent income rank is omitted. Fourth, the coefficients for prospective parent income rank are similar even when adjusting for the two sets of retrospective measures. Even when adjusting for retrospective measures, prospective parent income rank continue to have similar statistically and substantively significant coefficients. Thus, while parent income rank may be partly endogenous to these retrospective measures, including prospective measures adds to the effort to capture a more comprehensive understanding of the long arm of childhood.

Fifth, while the results favor prospective over retrospective measures, one can still find evidence for the long arm of childhood with retrospective measures. Both categories of father's educational attainment are significantly associated with all six mature adult health outcomes when omitting prospective measures. Indeed, father's education even statistically significantly predicts non-life-threatening chronic conditions (even though parent income rank does not). The model fits - with father's education and omitting prospective measures - are near the model fits in Table 1 as well. Among retrospective measures, the evidence slightly favors father's educational attainment over subjective economic standing. While both indicators of father's educational attainment significantly predict all outcomes, and the perception that parents were poor significantly predicts five outcomes (including non-life threatening chronic conditions but not stroke), the perception that parents were well off is insignificant for all outcomes.

Ultimately, Appendix C suggests that the evidence for the long arm of childhood is slightly stronger when using prospective measures. Most of the evidence supports the earlier theoretical and methodological arguments for prospective over retrospective measures. That said, researchers often only have retrospective measures. If prospective measures are unavailable, our evidence suggests father's educational attainment should be the preferred retrospective measure. 
Also, our results provide unique validation for studies based on retrospective measures by showing similar results with prospective measures. Retrospective father's education performs nearly as well as prospective parent income rank.

\section{Robustness Checks}

In addition to the alternative measures and Models in Appendices II-III, we conducted a variety of sensitivity tests. Again, the coefficients and model fit are summarized in Figures 1-2. Generally, these analyses confirm our results are robust.

Appendices IV-VI alter the samples from the sample of 40-65 year-old heads and spouses. Appendix D only includes respondents 50-65 years old given older populations have worse health (House et al. 1994). This provides a more conservative test as childhood conditions are more distal to 50-65 year olds. This results in a loss of approximately $45 \%$ of the sample so there is far less statistical power. Parent income rank still significantly predicts heart attack, stroke and life-threatening chronic condition. All signs are consistent with Table 1. However, the coefficients for self-rated health and psychological distress are not statistically significant. Appendix E expands the sample to $30-65$ year olds. This increases the sample size substantially so there is far more power. However, there is less heterogeneity in health among 30-39 year olds than among 40+ (House et al. 1994). Still, the results are generally consistent.

Appendix F only uses self-reports (of heads of households) and omits proxy reports

(usually of spouses). There is a substantial loss of cases - usually about $1 / 3^{\text {rd }}$ the sample. Partly for this reason, parent income rank has modestly smaller and only near significant coefficients for self-rated health, heart attack and stroke. However, Figure 1 also reveals slightly larger statistically significant coefficients for life threatening chronic condition and psychological 
distress. Moreover, Figure 2 shows the model fits improve when we omit proxy reports. Hence, the results are generally consistent if we only use self-reports.

Appendices G-H consider nonlinear functional forms for both parent income rank and absolute income. Appendix G features a log transformation and Appendix G displays a polynomial functional form. Both provide little evidence that a nonlinear functional form would be preferred to the linear functional forms. For example, Figure 2 shows model fit never meaningfully improves with a nonlinear functional form. Also, the squared terms are never statistically significant for parent relative income rank. ${ }^{10}$

\section{CONCLUSION}

Despite the contributions of the long arm literature, the field has previously been forced to rely on retrospective self-reports of childhood conditions and sub-optimal measures of childhood economic resources. We distinctively use prospective post-fisc equivalized parent income rank based on multiple observations during childhood in the 1970s-1980s. We link these measures to six health outcomes when respondents are aged 40-65. We adjust for several other childhood and individual characteristics. Altogether, we provide novel evidence for the long arm of childhood with prospective state-of-the-art income measures and a broad variety of salient mature adult health outcomes.

Our first two contributions are to: (a) assess prospective measures and, in the process, compare prospective and retrospective measures; and (b) improve the measurement of economic resources. The analyses demonstrate that prospective parent income rank has statistically and substantively significant relationships with five of six mature adult health outcomes. The relationships with heart attack, stroke and life threatening chronic conditions are particularly 
strong. Therefore, we provide novel evidence of the long arm of childhood with a prospective state-of-the-art measure of childhood income.

The PSID does not allow for an exact replication and comparison with all the retrospective measures used in prior studies. Still, we assess two sets of retrospective measures: father's education and family subjective economic standing. Our evidence suggests that prospective measures perform slightly better than retrospective measures. Yet, one can still assess the long arm of childhood with retrospective measures if prospective measures are not available. In the process, we provide critical validation of studies based on retrospective measures. Moreover, this is a novel validation as prior studies have heretofore not been able to compare optimal prospective and retrospective measures. Hence, this study buttresses past studies and guides ongoing studies using retrospective measures. Moreover, our distinctive comparison of prospective and retrospective measures clarifies which retrospective measures perform best and most similar to prospective measures. Among retrospective measures, father's education performs better than subjective economic standing.

On balance, the PSID does not have data on all aspects of childhood disadvantage. For example, there is considerable evidence for health effects of adverse life events during childhood (Lee and Ryff 2019). As well, it is plausible that unhealthy environments and poor health during childhood predict adult health. We focus more narrowly on childhood economic resources rather than all childhood conditions. We show that economic resources are one particularly salient aspect of childhood that is related to mature adult health. That said, economic resources likely predict and even cause many other unobserved childhood conditions and events. Parents with greater economic resources can "purchase" safer and healthier environments. In turn, their children should be less likely to experience accidents, toxicity, trauma, and injuries. Hence, 
childhood income likely serves as a fundamental cause of health by reducing the risks of adverse conditions (Link and Phelan 1995; Clouston and Link 2021).

Our third contribution is to inform several perennial debates about how best to measure and model how economic resources and social class shape health. First, we inform the debate between relative and absolute income. While relative income locates one hierarchically within the distribution of a time and place, absolute income's value is invariant across time and space. Our results are generally consistent as both relative and absolute childhood income robustly significantly predict mature adult health. However, the xstdB's and stdB's for parent relative income rank are always larger than those for parent absolute income. Compared to absolute income, the coefficients for relative income are about $11 \%$ larger for self-rated health, $47 \%$ larger for heart attack, $50 \%$ larger for stroke, 55\% larger for life-threatening chronic condition, and 52\% larger for psychological distress. Further, unlike parent relative income rank, parent absolute income is not statistically significant for heart attack. Overall, the evidence favors relative over absolute income - at least in terms of the predictive validity of childhood income for mature adult health.

Second, we inform debate about the salience of income compared to other measures of social class. Including two-digit occupation does not change inferences about childhood income or appreciably improve model fit. Also, the Models do not meaningfully improve with nonlinear functional forms for income. There appear to be at least mostly monotonic returns of parent income for mature adult health. Our results certainly support the implicit emphasis in the long arm literature on childhood disadvantage and adversity. However, our finding of a mostly linear relationship also illustrates the health advantages of childhood affluence. Our evidence suggests that children in high-income families benefit even compared to children in middle income 
families (Adler et al. 1994). There are meaningful health advantages to having a very high income, and this speaks to the health consequences of inequality alongside disadvantage (Elo 2009; Marmot 2005). An argument can be made for narrowing the gap between affluent and middle class in order to equalize mature adult health. This can complement raising the incomes of poor families to improve mature adult health decades later.

The results are also robust to several alternative samples and model specifications. We find similar results if we confine the sample to 50+ year olds, or expand the sample to include 30-39 year olds, or focus solely on self-reports of heads. Appendix J shows one final sensitivity analysis exploring different stages of childhood. As Appendix $\mathbf{J}$ shows, income during any stage of childhood is quite highly correlated with income at other stages or income across all of childhood (see Panel A). On one hand, this illustrates that it is extremely difficult to tease apart the long-term health effects of income across various stages of childhood (at least in observational data; see Panel B). On the other hand, this confirms that income at any stage of childhood and across childhood in general is similarly consequential to mature adult health.

The present study has limitations that can guide future research. First, upcoming waves of surveys like the PSID could include the survey questions used to form prior composite indices of retrospective childhood disadvantage. This would allow an even closer comparison of prospective and retrospective measures. Second, other datasets besides the PSID are needed to study Asian American, Latino and immigrant populations and ethno-racial minorities besides black people. Third, how race and sex interact with childhood income to drive race and sex inequalities in mature adult health is beyond our scope but warrants attention. Fourth, the political-economic context of childhood varies in terms of social policies and institutions such as labor unions (VanHeuvelen and Brady Forthcoming). Future research should analyze if such 
contextual factors moderate the relationship between childhood income and mature adult health. Fifth, future PSID analyses can build on recent research that investigates the mechanisms at work in the long arm of childhood (e.g. Lee and Ryff 2019; Montez et al. 2016; Morton and Ferraro 2020). Because the PSID-CNEF has a large number of respondents followed over a long period of time - from childhood through mature adulthood - future analyses should investigate the potential mechanisms after childhood but before mature adulthood (e.g. ages 18-39), including health behaviors and economic attainment.

Altogether, this study buttresses the case for the long arm of childhood. We uniquely demonstrate precisely how economic resources translate into health via prospective parent income rank. This should invite public policy debate. The broader concept implied by composite indices of childhood disadvantage is fairly diffuse and intervening on such indices is therefore challenging. For composite childhood disadvantage, we do not know which specific indicators to prioritize nor do we know that intervening on any particular indicator will necessarily improve adult health. By contrast, our evidence suggests policymakers can intervene with income transfers targeted at children to improve adult health. Policymakers can also equalize health by taxing high-income families. Altogether, this study suggests that raising and equalizing incomes during childhood can have long-term and equalizing health benefits much later in adulthood. 


\section{SUPPLEMENTARY MATERIAL}

See Online Appendix after Tables.

\section{ACKNOWLEDGEMENTS}

We thank Elizabeth Lawrence, Mark Pachuki, and JHSB reviewers for comments. The second through fourth authors are listed alphabetically to denote equal contributions.

\section{FUNDING}

This project was funded by National Institute of Aging, R03 Grant 1R03AG062842-01A1.

\section{NOTES}

1 This reduces sample attrition as we only require one observation at age $40+$ regardless of when. If we focused only on respondents aged 40+ in the 2019 wave instead of the last available wave for each respondent $40+$, the sample size would be roughly $20 \%$ smaller. Also, if death occurs after age 40, we can use the last available observation. About 5\% of the potential sample (i.e. children 0-17 in 1970-1996 waves with two income observations) died by 2019.

2 In analyses available upon request, we found similar results when combining these two into a general measure of acute health events. The Center for Disease Control (https://www.cdc.gov/nchs/hus/contents2019.htm\#Table-013) shows our estimates are similar to national estimates in 2017-2018 for 45-64 years olds for heart disease/attack (11.8\%) and stroke (3.2\%). Although we include cancer among life-threatening chronic conditions, $8.0 \%$ of our sample has had cancer, which is similar to the CDC estimate of $7.1 \%$. 
3 In analyses available upon request, we combined all seven conditions into one measure, which yielded results similar to those for life threatening chronic conditions. More than $60 \%$ of the sample has at least one of these conditions and there is considerable co-morbidity.

$4 \quad$ By including these other family background characteristics, we acknowledge that family background embodies a host of health benefits, many of which are not strictly economic (Elo 2009; Herd et al. 2007; Geyer et al. 2006; Schnittker 2004). Still, we caution against comparing the coefficients of these characteristics against those for parent income because parent income is posttreatment to and mediates some of the effects of these characteristics (e.g. Elo 2009).

5 We report standardized coefficients to facilitate comparison of the substantive magnitude of coefficients across outcomes and across independent variables.

6 Because the standard deviation in parent income rank is 23.79 (see Appendix A), one can multiply the stdBs and xstdB's by about 2.1 to predict the change in outcomes associated with a change from $25^{\text {th }}$ to $75^{\text {th }}$ percentile in parent income rank. Similarly, a change from $10^{\text {th }}$ to $90^{\text {th }}$ percentile can be estimated by multiplying the stdBs and xstdB's by about 3.36 .

7 This also explains the lack of racial and sex disparities in mature adult health. Note that the bivariate correlations are as expected (see Appendix A). However, the observed parent characteristics mediate the relationship between respondent race and health (Brady et al. 2020). If we omit only parent income rank and lead education, black respondents have worse mature adult health. Although female respondents are not significantly different, recall most PSID heads are male, and spouses' health are proxy reports. Proxy reports likely attenuate estimates of women's adverse health (cf. Appendix F). For instance, if we solely focus on self-reporting female heads, female respondents have worse mature adult health. 
8 Having a higher $\mathrm{N}$ is an additional benefit of prospective over retrospective measures as non-response is unlikely to be randomly assigned. Again, the bottom of Appendix C shows very similar results for prospective parent income rank if the Ns are confined to cases non-missing on the retrospective measures.

9 Indeed, parent income rank correlates moderately and positively with retrospective father high school degree and with father college degree. Also, parent income rank correlates moderately and negatively with retrospective subjective judgment that parents were poor and weakly and positively that parents were well off.

10 The squared terms are statistically significant for absolute income for four outcomes. However, the attenuation in the coefficients implied by the squared terms are not substantively significant. Although the increases in health for higher absolute incomes slow down at some point, the health benefits of higher absolute income continue at quite high incomes. 


\section{REFERENCES}

Adler, Nancy E., Thomas Boyce, Margaret A. Chesney, Sheldon Cohen, Susan Folkman, Robert L. Kahn, and Leonard S. Syme. 1994. "Socioeconomic status and health: The challenge of the gradient." American Psychologist 49: 15-24.

Avendano, Mauricio. 2012. "Correlation or causation? Income inequality and infant mortality in fixed effects models in the period 1960-2008 in 34 OECD countries." Social Science \& Medicine 75: 754-760.

Avendano Mauricio and M. Maria Glymour. 2008. "Stroke disparities in older Americans: is wealth a more powerful indicator of risk than income and education?" Stroke 39: 153340.

Bartfeld, Judith, Craig Gundersen, Timothy M. Smeeding, and James P. Ziliak, editors. 2015. SNAP matters: how food stamps affect health and well-being Stanford: Stanford University Press.

Benyamini, Yael and Ellen L. Idler. 1999. "Community studies reporting association between self-rated health and mortality: additional studies, 1996-1998." Research on Aging 21: $392-401$.

Blau, David M. 1999. “The effect of income on child development." The Review of Economics and Statistics 81: 261-76.

Brady, David, Ryan Finnigan, Ulrich Kohler, and Joscha Legewie. 2020. "The inheritance of race revisited: childhood wealth and income, and black-white disadvantages in adult life chances.” Sociological Science 7: 599-627. 
Brady, David, Marco Giesselman, Ulrich Kohler, and Anke Radenacker. 2018. "How to measure and proxy permanent Income: evidence from Germany and the U.S.” Journal of Economic Inequality 16: 321-45.

Brady, David and Zachary Parolin. 2020. "The levels and trends in deep and extreme poverty in the U.S., 1993-2016.” Demography 57: 2337-2360.

Case, Anne, Darren Lubotsky, and Christina Paxson. 2002. "Economic status and health in childhood: the origins of the gradient." American Economic Review 92: 1308-1334.

Chetty Raj, Michael Stepner, Sarah Abraham, Shelby Lin, Benjamin Scuderi, Nicholas Turner, Augustin Bergeron, and David Cutler. 2016. "The association between income and life expectancy in the United States, 2001-2014." Journal of the American Medical Association 315: 1750-66.

Clouston, Sean AP, and Bruce G. Link. 2021. "A retrospective on fundamental cause theory: state of the literature and goals for the future." Annual Review of Sociology 47: 131-156.

Daly, Mary C., Greg J. Duncan, Peggy McDonough and David R. Williams. 2002. “Optimal indicators of socioeconomic status for health research." American Journal of Public Health 92: 1151-1157.

Deaton, Angus. 2015. The Great Escape Princeton, NJ: Princeton University Press.

Duncan Greg J., Katherine Magnuson, Ariel Kalil, Kathleen M. Ziol-Guest. 2012. "The importance of early childhood poverty." Social Indicators Research 108: 87-98.

Duncan, Greg J. and Eric Petersen. 2001. "The long and short of asking questions about income, wealth, and labor supply." Social Science Research 30: 248-263.

Duncan, Greg J., Kathleen M. Ziol-Guest, and Ariel Kalil. 2010. "Early childhood poverty and adult attainment, behavior and health." Child Development 81: 306-25. 
Dupre, Matthew E, Linda K. George, Guangya Liu, and Eric D. Peterson. 2012. "The cumulative effect of unemployment on risks for myocardial infarction." Archives of Internal Medicine 172: 1731-1737.

Easterlin, Richard A., Laura A. McVey, Malgorzata Switek, Onnicha Sawangfa, and Jacqueline S. Zweig. 2010. “The happiness-income paradox revisited.” Proceedings of the National Academy of Sciences 107: 22463-22468.

Elo, Irma. 2009. "Social class differentials in health and mortality: patterns and explanations in comparative perspective." Annual Review of Sociology 35: 553-572.

Ferraro, Kenneth F., Markus H. Schafer, and Lindsay R. Wilkinson. 2015. “Childhood disadvantage and health problems in middle and later life." American Sociological Review 81: 107-133.

Fox, Liana, Florencia Torche, and Jane Waldfogel. "Intergenerational mobility.” Pp. 528-554 in The Oxford Handbook of the Social Science of Poverty, edited by D. Brady and L.M. Burton. New York: Oxford University Press.

Frick, Joachim R., Stephen P. Jenkins, Dean R. Lillard, Oliver Lipps, and Mark Wooden. 2007. "The cross-national equivalent file (CNEF) and its member country household panel studies." Schmoller's Jahrbuch 127: 627-54.

Geyer, Siegfried, Orjan Hemström, Richard Peter, and Denny Vågerö. 2006. “Education, income, and occupational class cannot be used interchangeably in social epidemiology: empirical evidence against a common practice." Journal of Epidemiology \& Community Health 60: 804-10. 
Gilman, Stephen E., Ichiro Kawachi, Garrett M. Fitzmaurice, and Stephen L. Buka. 2002. "Socioeconomic status in childhood and the lifetime risk of major depression." International Journal of Epidemiology 31: 359-367.

Gundersen, Craig and James P. Zilliak. 2003. "The role of food stamps in consumption stabilization." Journal of Human Resources 38: 1051-79

Hamil-Luker Jennifer and Angela M. O’Rand. 2007. “Gender differences in the link between childhood socioeconomic conditions and heart attack risk in adulthood." Demography 44: 137-158.

Hardt, Jochen and Michael Rutter. 2004. "Validity of adult retrospective reports of adverse childhood experiences: review of evidence.” Journal of Child Psychology \& Psychiatry 45: $260-273$.

Hayward Mark D. and Bridget K. Gorman. 2004. "The long arm of childhood: the influence of early-life social conditions on men's mortality.” Demography 41: 87-107.

Herd, Pamela, Brian Goesling, and James S. House. 2007. "Socioeconomic position and health: the differential effects of education versus income on the onset versus progression of health problems." Journal of Health and Social Behavior 48: 223-238.

Hoynes, Hilary and Diane Whitmore Schanzenbach, and Douglas Almond. 2016. "Long run impacts of childhood access to the safety net." American Economic Review 106: 903-934.

House, James S., James M. Lepkowski, Ann M. Kinney, Richard P. Mero, Ronald C. Kessler, and A. Regula Herzog. 1994. "The social stratification of aging and health." Journal of Health \& Social Behavior 35: 213-234. 
Jefferis, Barbara JMH, Chris Power, and Clyde Hertzman. 2002. "Birth weight, childhood socioeconomic environment, and cognitive development in the 1958 British birth cohort study." BMJ 325: 305.

Johnson, Rucker C. and Robert F. Schoeni. 2011. "Early-life origins of adult disease: national longitudinal population-based study of the United States." American Journal of Public Health 101: 2317-2324.

Kauhanen, Laura, Hanna-Maaria Lakka, John W. Lynch, and Jussi Kauhanen. 2006. "Social disadvantages in childhood and risk of all-cause death and cardiovascular disease in later life: a comparison of historical and retrospective childhood information." International Journal of Epidemiology 35: 962-968.

Kessler, RC., G. Andrews, L.J. Colpe, E. Hiripi, D.K. Mroczek, L.T. Normand, E.E. Walters, and A.M. Zaslavsky. 2002. "Short screening scales to monitor population prevalences and trends in non-specific psychological distress." Psychological Medicine 32: 959-976.

Kuh, Diana, Rebecca Hardy, Claudia Langenberg, Marcus Richards, and Michael E.J. Wadsworth. 2002. "Mortality in adults aged 25-64 years related to socioeconomic conditions in childhood and adulthood: post war birth cohort study." BMJ 325:10761080.

Ladin, Keren, Norman Daniels, and Ichiro Kawachi. 2010. "Exploring the relationship between absolute and relative position and late-life depression: Evidence from 10 European countries." Gerontologist 50: 48-59.

Laditka, Sarah B. and James N. Laditka. 2018. “An enduring health risk of childhood adversity: earlier, more severe, and longer lasting disability in adult life." Journal of Gerontology B: Psychological Sciences and Social Sciences 74: 136-147 
Lee, Chioun, and Carol D. Ryff. 2019. "Pathways linking combinations of early-life adversities to adult mortality: tales that vary by gender." Social Science \& Medicine 240.

Lillard, Dean R., Richard V. Burkhauser, Markus H. Hahn, and Roger Wilkins. 2015. "Does early-life income inequality predict self-reported health later in life?: evidence from the United States." Social Science \& Medicine 128: 347-355.

Link, Bruce G. and Jo Phelan. 1995. "Social conditions as fundamental causes of disease." Journal of Health \& Social Behavior Special Issue: 80-94.

Link, Bruce G., Ezra S. Susser, Pam Factor-Litvak, Dana March, Katrina L. Kezios, Gina S. Lovasi, Andrew G. Rundle, Shakira F. Suglia, Kim M. Fader, Howard F. Andrews, Eileen Johnson, Piera M. Cirillo, and Barbara A. Cohn. 2017. "Disparities in self-rated health across generations and through the life course." Social Science \& Medicine 174: $17-25$.

Luo, Ye and Linda J. Waite. 2005. "The impact of childhood and adult SES on physical, mental, and cognitive well-being in later life." Journal of Gerontology B: Psychological Sciences and Social Sciences 60: S93-S101.

Marmot, Michael. 2005. "Social determinants of health inequalities." The Lancet 365: 19-25. Martikainen, Pekka, Irma Elo, Lasse Tarkiainen, Janne Mikkonen, Mikko Myrskylä, and Heta Moustgaard. 2020. "The changing contribution of childhood social characteristics to mortality: a comparison of Finnish cohorts born in 1936-50 and 1960-75." International Journal of Epidemiology 49: 896-907.

Mazumder, Bhashkar. 2016. "Estimating the intergenerational elasticity and rank association in the United States: overcoming the current limitations of tax data. Pp. p. 83-129 in 
Inequality: causes and consequences, research in labor economics, edited by S Polachek \& K Tatsiramos. Bingley: Emerald Group Publishing Limited.

Melchior, Maria, Terrie E. Moffitt, Barry J. Milne, Richie Poulton, and Avshalom Caspi. 2007. "Why do children from socioeconomically disadvantaged families suffer from poor health when they reach adulthood?: a life course study.” American Journal Epidemiology 166: $966-974$.

McLeod, Jane D. and Michael J. Shanahan. 1996. “Trajectories of poverty and children's mental health." Journal of Health \& Social Behavior 37: 207-220.

Montez, Jennifer K. and Mark D. Hayward. 2014. "Cumulative childhood adversity, educational attainment, and active life expectancy among U.S. adults." Demography 51: 413-435.

Montez, Jennifer K., Joyce T. Bromberger, Sioban D. Harlow, Howard M. Kravitz, Karen A. Matthews. 2016. "Life-course socioeconomic status and metabolic syndrome among midlife women.” Journals of Gerontology Series B: Psychological Sciences and Social Sciences 71: 1097-1107.

Moorman, Sara M., Emily A. Greenfield, and Sarah Garcia. 2019. "School context in adolescence and cognitive functioning 50 Years later." Journal of Health \& Social Behavior 60: 493-508.

Morton, Patricia M. and Kenneth F. Ferraro. 2020. "Early social origins of biological risks for men and women in later life." Journal of Health \& Social Behavior 61: 503-522.

Morton, Patricia M., Sarah A. Mustillo, and Kenneth F. Ferraro. 2014. "Does childhood misfortune raise the risk of acute myocardial infarction in adulthood?" Social Science \& Medicine 104: 133-141.

Panel Study of Income Dynamics (PSID) [dataset]. Ann Arbor (MI): 2013. 
Poulton, Richie, Avshalom Caspi, Barry J. Milne, W. Murray Thomson, Alan Taylor, Malcolm R. Sears, and Terrie E. Moffitt. 2002. “Association between children's experience of socioeconomic disadvantage and adult health: a life course study." The Lancet 360: 16401645.

Rainwater Lee and Timothy M. Smeeding. 2004. Poor kids in a rich country New York: Russell Sage Foundation.

Robins, Lee N., Sandra P. Schoenberg, Sandra J. Holmes, Kathryn S. Ratcliff, Alexandra Benham, and Jane Works. 1985. "Early home environment and retrospective recall: A test of concordance between siblings with and without psychiatric disorders." American Journal of Orthopsychiatry 55: 27-41.

Schacter, Daniel L. 2001. The seven sins of memory: how the mind forgets and remembers. Boston, MA: Houghton Mifflin Company.

Schafer, Markus H. and Kenneth F. Ferraro. 2011. "Childhood misfortune as a threat to successful aging: avoiding disease.” The Gerontologist 52: 111-120.

Schafer, Markus H., Kenneth F. Ferraro, and Sarah A. Mustillo. 2011. "Children of misfortune: early adversity and cumulative inequality in perceived life trajectories." American Journal of Sociology 116: 1053-1091.

Schnittker, Jason. 2004. "Education and the changing shape of the income gradient in health." Journal of Health \& Social Behavior 45: 286-305.

Schnittker, Jason, and Valerio Bacak. 2014. "The increasing predictive validity of self-rated health." PLOS One 9: 1-11. 
Shuey, Kim M. and Andrea E. Wilson. 2014. "Economic hardship in childhood and adult health trajectories: an alternative approach to investigating life-course processes." Advances in Life Course Research 22: 49-61.

Smeeding, Timothy M. and Daniel H. Weinberg. 2003. "Toward a uniform definition of household income." Review of Income \& Wealth 47: 1-24.

Song Xi and Robert D. Mare. 2014. "Retrospective versus prospective approaches to the study of intergenerational social mobility." Sociological Methods \& Research 44: 555-584.

Stevenson, Betsey and Justin Wolfers. 2013. "Subjective well-being and income: is there any evidence of satiation?" American Economic Review 103: 598-604.

Turner, R. Jay, Courtney S. Thomas, and Tyson H. Brown. 2016. "Childhood adversity and adult health: evaluating intervening mechanisms." Social Science \& Medicine 156: 114-124.

United Nations Economic Commission for Europe. 2011. Canberra group handbook on household income statistics, 2nd edition. Geneva: United Nations.

VanHeuvelen, Tom and David Brady. Forthcoming. "Labor unions and American poverty." ILR Review.

Vartanian, Thomas P. and Linda Houser. 2010. "The effects of childhood neighborhood conditions on self-reports of adult health." Journal of Health \& Social Behavior 51: 291306.

Veenhoven, Ruut. 1991. “Is happiness relative?" Social Indicators Research 24: 1-34.

Warner, David F. and Mark D. Hayward. 2006. "Early-life origins of the race gap in men's mortality." Journal of Health \& Social Behavior 47: 209-226. 
Wilson, Andrea E., Kim M. Shuey, and Glenn H. Elder Jr. 2007. “Cumulative advantage processes as mechanisms of inequality in life course health.” American Journal of Sociology 112: 1886-1924.

Yang, Yang C., Kristen Schorpp, Courtney Boen, Moira Johnson, and Kathleen M. Harris. 2020. "Socioeconomic status and biological risks for health and illness across the life course." Journals of Gerontology: Social Sciences 75: 613-624.

Zheng, Hui, Jonathan Dirlam, and Paola Echave. 2020. "Divergent trends in the effects of early life factors on adult health." Population Research and Policy Review.

Ziol-Guest, Kathleen M., Greg J. Duncan, and Ariel Kalil. 2009. "Early childhood poverty and adult body mass index.” American Journal of Public Health 99: 527-532. 


\section{AUTHOR BIOS}

David Brady is professor in the School of Public Policy at the University of California at Riverside. He is also a research professor on inequality and social policy at the WZB Berlin Social Science Center. He studies poverty, racial and health inequalities, social policy, and the political consequences of immigration and ethno-racial diversity. He is the author of Rich Democracies, Poor People and editor of The Oxford Handbook of the Social Science of Poverty.

Christian Guerra is a $\mathrm{PhD}$ candidate in the sociology department at the University of California, Riverside. His research focuses on assessing and predicting area-level mortality rates using Google search term data in the US. He is currently focused on suicides, overdoses, and alcohol-related deaths.

Ulrich Kohler is a professor of methods of empirical social research in the department for economics and social science of the University of Potsdam. He is editor of Survey Research Methods. Current research interests include health consequences of economic positions in the childhood, the social roots of learning ancient languages, and the usage of non-probability samples for sociological research. He recently published "Educational Expansion, Social Class, and Choosing Latin as a Strategy of Distinction” in Zeitschrift für Soziologie.

Bruce G. Link is Distinguished Professor of public policy and sociology at the University of California, Riverside. He is currently conducting research on the life course origins of health inequalities by race-ethnicity and socioeconomic status, the consequences of social stigma for the life chances of people who are subject to stigma, and intervention efforts aimed at reducing mental illness stigma in children attending middle school. 


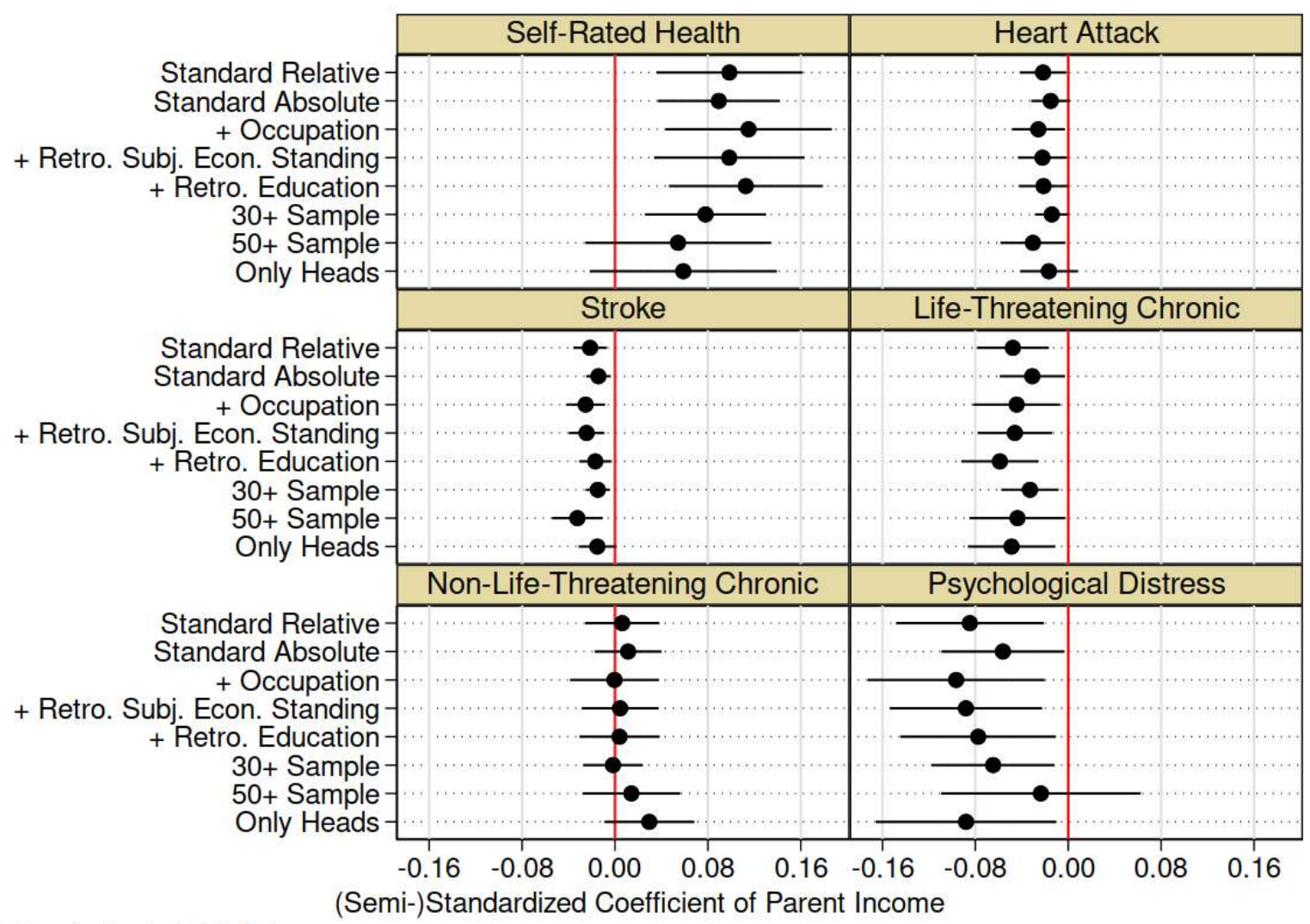

Spikes indicate $95 \%$ C.I.

Figure 1. Parent Income Coefficients (stdB's of xstdB's for binary outcomes) Coefficients Across Table 1 and Online Appendices. 


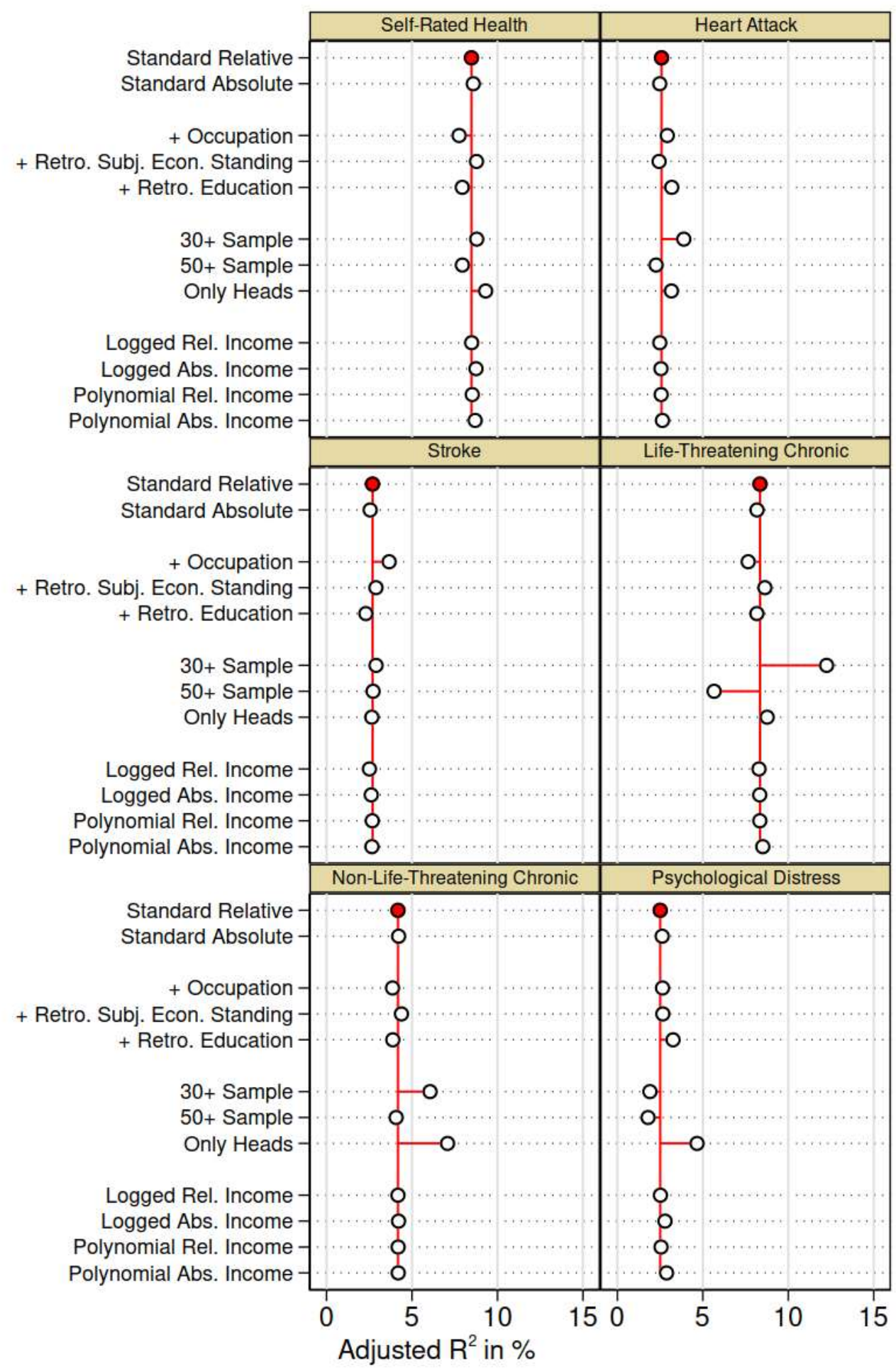

Figure 2. Adjusted $\mathrm{R}^{2}$ 's for Various Models Across Table 1 and Online Appendices. 
Table 1. Standardized and X-Standardized Coefficients from Linear Models for Health Outcomes at 40+ on Childhood Income Rank and Other Variables.

\begin{tabular}{|c|c|c|c|c|c|c|}
\hline & $\begin{array}{c}\text { Self- } \\
\text { Rated } \\
\text { Health }\end{array}$ & $\begin{array}{l}\text { Heart } \\
\text { Attack }\end{array}$ & Stroke & $\begin{array}{c}\text { Life- } \\
\text { Threatening } \\
\text { Chronic } \\
\end{array}$ & $\begin{array}{l}\text { Non-Life- } \\
\text { Threatening } \\
\text { Chronic } \\
\end{array}$ & $\begin{array}{l}\text { Psychological } \\
\text { Distress }\end{array}$ \\
\hline $\begin{array}{l}\text { Parent } \\
\text { Income } \\
\text { Rank }\end{array}$ & $\begin{array}{l}.099^{* * *} \\
(.032)\end{array}$ & $\begin{array}{l}.022^{*} \\
(.010)\end{array}$ & $\begin{array}{l}.021^{* *} \\
(.007)\end{array}$ & $\begin{array}{c}.048^{* *} \\
(.016)\end{array}$ & $\begin{array}{c}.006 \\
(.016)\end{array}$ & $\begin{array}{l}.085^{* *} \\
(.032)\end{array}$ \\
\hline $\begin{array}{l}\text { Lead } \\
\text { Education }\end{array}$ & $\begin{array}{l}.184^{* *} \\
(.026)\end{array}$ & $\begin{array}{l}-.018^{*} \\
(.009)\end{array}$ & $\begin{array}{l}-.010 \\
(.007)\end{array}$ & $\begin{array}{l}-.035^{* *} \\
(.013)\end{array}$ & $\begin{array}{l}-.027^{*} \\
(.013)\end{array}$ & $\begin{array}{l}-.082^{* *} \\
(.028)\end{array}$ \\
\hline Lead Age & $\begin{array}{l}.002 \\
(.023)\end{array}$ & $\begin{array}{l}-.001 \\
(.007)\end{array}$ & $\begin{array}{l}.008 \\
(.006)\end{array}$ & $\begin{array}{l}-.009 \\
(.011)\end{array}$ & $\begin{array}{l}.002 \\
(.011)\end{array}$ & $\begin{array}{l}.030 \\
(.024)\end{array}$ \\
\hline $\begin{array}{l}\text { Sibship } \\
\text { Size }\end{array}$ & $\begin{array}{l}.031 \\
(.024)\end{array}$ & $\begin{array}{l}.001 \\
(.008)\end{array}$ & $\begin{array}{l}-.005 \\
(.005)\end{array}$ & $\begin{array}{r}-.020 \\
(.011)\end{array}$ & $\begin{array}{l}-.015 \\
(.012)\end{array}$ & $\begin{array}{l}-.028 \\
(.022)\end{array}$ \\
\hline $\begin{array}{l}\text { Single } \\
\text { Motherhood }\end{array}$ & $\begin{array}{l}-.056^{*} \\
(.025)\end{array}$ & $\begin{array}{l}.004 \\
(.009)\end{array}$ & $\begin{array}{l}-.001 \\
(.006)\end{array}$ & $\begin{array}{l}.005 \\
(.012)\end{array}$ & $\begin{array}{l}.025^{*} \\
(.012)\end{array}$ & $\begin{array}{l}.036 \\
(.029)\end{array}$ \\
\hline Age & $\begin{array}{l}-.117^{* *} \\
(.024)\end{array}$ & $\begin{array}{l}.035^{* *} \\
(.008)\end{array}$ & $\begin{array}{l}.023^{* *} \\
(.006)\end{array}$ & $\begin{array}{l}.124^{* *} \\
(.012)\end{array}$ & $\begin{array}{l}.062^{* *} \\
(.012)\end{array}$ & $\begin{array}{l}-.080^{* *} \\
(.025)\end{array}$ \\
\hline Black & $\begin{array}{l}.049 \\
(.066)\end{array}$ & $\begin{array}{l}-.015 \\
(.023)\end{array}$ & $\begin{array}{l}.007 \\
(.017)\end{array}$ & $\begin{array}{l}.040 \\
(.030)\end{array}$ & $\begin{array}{l}-.007 \\
(.032)\end{array}$ & $\begin{array}{l}-.253^{* *} \\
(.064)\end{array}$ \\
\hline Latino & $\begin{array}{l}.497 \\
(.329)\end{array}$ & $\begin{array}{l}-.117 \\
(.060)\end{array}$ & $\begin{array}{l}.019 \\
(.030)\end{array}$ & $\begin{array}{l}-.227^{*} \\
(.106)\end{array}$ & $\begin{array}{l}.158 \\
(.363)\end{array}$ & $\begin{array}{l}.340 \\
(.455)\end{array}$ \\
\hline Other Race & $\begin{array}{l}.042 \\
(.095)\end{array}$ & $\begin{array}{l}.026 \\
(.036)\end{array}$ & $\begin{array}{l}.026 \\
(.030)\end{array}$ & $\begin{array}{l}-.040 \\
(.059)\end{array}$ & $\begin{array}{l}-.058 \\
(.051)\end{array}$ & $\begin{array}{l}-.086 \\
(.120)\end{array}$ \\
\hline Female & $\begin{array}{l}-.044 \\
(.041)\end{array}$ & $\begin{array}{l}-.001 \\
(.013)\end{array}$ & $\begin{array}{l}.013 \\
(.010)\end{array}$ & $\begin{array}{l}-.027 \\
(.020)\end{array}$ & $\begin{array}{l}.103^{* *} \\
(.021)\end{array}$ & $\begin{array}{l}.092^{*} \\
(.044)\end{array}$ \\
\hline Constant & $\begin{array}{l}-.228 \\
(.388)\end{array}$ & $\begin{array}{l}.039 \\
(.024)\end{array}$ & $\begin{array}{l}.107 \\
(.085)\end{array}$ & $\begin{array}{l}.543^{* *} \\
(.198)\end{array}$ & $\begin{array}{l}1.016^{* *} \\
(.085)\end{array}$ & $\begin{array}{l}-.305^{*} \\
(.124)\end{array}$ \\
\hline $\begin{array}{l}\mathrm{N} \\
\text { Adjusted } \mathrm{R}^{2}\end{array}$ & $\begin{array}{r}3884 \\
.085 \\
\end{array}$ & $\begin{array}{l}3944 \\
.026 \\
\end{array}$ & $\begin{array}{l}3944 \\
.027 \\
\end{array}$ & $\begin{array}{r}3862 \\
.083 \\
\end{array}$ & $\begin{array}{r}3813 \\
.042 \\
\end{array}$ & $\begin{array}{r}3894 \\
.025 \\
\end{array}$ \\
\hline
\end{tabular}

The numbers in parentheses are robust standard errors clustered by household. All Models include wave indicators (not shown).

** $\mathrm{p}<.01,{ }^{*} \mathrm{p}<.05$ (two-tailed tests) 
ONLINE APPENDIX

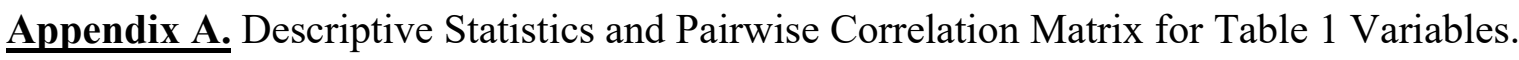

\begin{tabular}{|c|c|c|c|c|c|c|c|c|c|c|c|c|c|c|c|c|c|}
\hline & Mean & SD & 1 & 2 & 3 & 4 & 5 & 6 & 7 & 8 & 9 & $\mathbf{1 0}$ & 11 & 12 & 13 & 14 & 15 \\
\hline 1) Self-Rated Health & 3.33 & 1.05 & 1.00 & & & & & & & & & & & & & & \\
\hline 2) Heart Attack & .11 & .31 & -.25 & 1.00 & & & & & & & & & & & & & \\
\hline 3) Stroke & .05 & .22 & -.24 & .24 & 1.00 & & & & & & & & & & & & \\
\hline $\begin{array}{l}\text { 4) Life-Threatening } \\
\text { Chronic }\end{array}$ & .46 & .50 & -.36 & .20 & .17 & 1.00 & & & & & & & & & & & \\
\hline $\begin{array}{l}\text { 5) Non-Life-Threatening } \\
\text { Chronic }\end{array}$ & .41 & .49 & -.31 & .17 & .12 & .21 & 1.00 & & & & & & & & & & \\
\hline 6) Psychological Distress & 3.42 & 4.23 & -.38 & .12 & .14 & .12 & .21 & 1.00 & & & & & & & & & \\
\hline 7) Parent Income Rank & 47.70 & 23.79 & .21 & -.08 & -.10 & -.12 & .00 & -.08 & 1.00 & & & & & & & & \\
\hline 8) Lead Education & 12.15 & 2.86 & .24 & -.11 & -.12 & -.19 & -.06 & -.05 & .56 & 1.00 & & & & & & & \\
\hline 9) Lead Age & 39.02 & 7.69 & -.03 & .04 & .04 & .06 & .05 & -.04 & .18 & -.20 & 1.00 & & & & & & \\
\hline 10) Sibship Size & 1.78 & 1.32 & -.09 & .06 & .06 & .10 & .01 & -.01 & -.38 & -.32 & .05 & 1.00 & & & & & \\
\hline 11) Single Motherhood & .14 & .27 & -.10 & .03 & .07 & .06 & .02 & .04 & -.49 & -.13 & -.20 & .09 & 1.00 & & & & \\
\hline 12) Age & 52.26 & 7.26 & -.13 & .12 & .10 & .26 & .13 & -.07 & .08 & -.19 & .32 & .20 & -.03 & 1.00 & & & \\
\hline 13) Black & .14 & .34 & -.16 & .05 & .10 & .14 & .00 & .00 & -.59 & -.42 & -.03 & .33 & .40 & .04 & 1.00 & & \\
\hline 14) Latino & .001 & .03 & .01 & -.01 & -.01 & -.03 & .01 & .00 & -.01 & -.02 & -.02 & .01 & -.02 & -.05 & -.04 & 1.00 & \\
\hline 15) Other Race & .04 & .19 & -.03 & .04 & .02 & .01 & .01 & .02 & -.03 & -.04 & -.01 & .02 & -.02 & .00 & -.16 & -.01 & 1.00 \\
\hline 16) Female & .51 & .50 & -.07 & .03 & .04 & .03 & .12 & .05 & -.10 & -.07 & -.01 & .05 & .09 & .03 & .09 & .00 & .02 \\
\hline
\end{tabular}

Note: $\mathrm{N}=3690$ for descriptives based on casewise deletion. The correlations are pairwise, so the $\mathrm{N}$ depends on variables.

Standardization of variables in Models above is based on separate samples with casewise deletion for each outcome. 
Appendix B. Standardized and X-Standardized Coefficients from Alternative Linear Models Including Absolute Income and Occupation for Health Outcomes at 40+.

\begin{tabular}{|c|c|c|c|c|c|c|}
\hline & $\begin{array}{l}\text { Self-Rated } \\
\text { Health }\end{array}$ & $\begin{array}{l}\text { Heart } \\
\text { Attack }\end{array}$ & Stroke & $\begin{array}{c}\text { Life- } \\
\text { Threatening } \\
\text { Chronic } \\
\end{array}$ & $\begin{array}{c}\text { Non-Life- } \\
\text { Threatening } \\
\text { Chronic } \\
\end{array}$ & $\begin{array}{c}\text { Psychological } \\
\text { Distress }\end{array}$ \\
\hline Parent Income Rank & $\begin{array}{l}.099^{* *} \\
(.032)\end{array}$ & $\begin{array}{l}-.022^{*} \\
(.010)\end{array}$ & $\begin{array}{c}\text { ble } 1 \text { Res } \\
-.021^{* *} \\
(.007)\end{array}$ & $\begin{array}{l}-.048^{* *} \\
(.016)\end{array}$ & $\begin{array}{l}.006 \\
(.016)\end{array}$ & $\begin{array}{l}-.085^{* *} \\
(.032)\end{array}$ \\
\hline $\begin{array}{l}\mathrm{N} \\
\text { Adjusted } \mathrm{R}^{2}\end{array}$ & $\begin{array}{c}3884 \\
.085 \\
\end{array}$ & $\begin{array}{c}3944 \\
.026 \\
\end{array}$ & $\begin{array}{c}3944 \\
.027\end{array}$ & $\begin{array}{c}3862 \\
.083 \\
\end{array}$ & $\begin{array}{l}3813 \\
.042 \\
\end{array}$ & $\begin{array}{c}3894 \\
.025\end{array}$ \\
\hline $\begin{array}{l}\text { Parent Absolute } \\
\text { Income }\end{array}$ & $\begin{array}{l}.089^{* *} \\
(.027)\end{array}$ & $\begin{array}{l}-.015 \\
(.009)\end{array}$ & $\begin{array}{c}\text { olute Inc } \\
-.014^{* *} \\
(.005)\end{array}$ & $\begin{array}{l}-.031^{*} \\
(.014)\end{array}$ & $\begin{array}{l}.011 \\
(.015)\end{array}$ & $\begin{array}{l}-.056^{*} \\
(.027)\end{array}$ \\
\hline $\begin{array}{l}\mathrm{N} \\
\text { Adjusted } \mathrm{R}^{2}\end{array}$ & $\begin{array}{c}3996 \\
.086\end{array}$ & $\begin{array}{r}4061 \\
.025\end{array}$ & $\begin{array}{r}4061 \\
.026\end{array}$ & $\begin{array}{l}3974 \\
.082\end{array}$ & $\begin{array}{l}3924 \\
.042\end{array}$ & $\begin{array}{r}4029 \\
.026\end{array}$ \\
\hline Parent Income Rank & $\begin{array}{l}.115^{* *} \\
(.037)\end{array}$ & $\begin{array}{l}\quad \text { Incl } \\
-.026^{*} \\
(.012)\end{array}$ & $\begin{array}{l}\text { 2-digit } \\
-.025^{* *} \\
(.009)\end{array}$ & $\begin{array}{l}\text { upation } \\
-.044^{*} \\
(.019)\end{array}$ & $\begin{array}{l}-.000 \\
(.020)\end{array}$ & $\begin{array}{l}-.097^{*} \\
(.039)\end{array}$ \\
\hline $\begin{array}{l}\mathrm{N} \\
\text { Adjusted } \mathrm{R}^{2}\end{array}$ & $\begin{array}{c}2992 \\
.078\end{array}$ & $\begin{array}{c}3049 \\
.029\end{array}$ & $\begin{array}{r}3049 \\
.037\end{array}$ & $\begin{array}{c}2979 \\
.077\end{array}$ & $\begin{array}{r}2949 \\
.039\end{array}$ & $\begin{array}{l}3034 \\
.026\end{array}$ \\
\hline
\end{tabular}

Note: The Ns are very slightly different between absolute income and income rank because weights were not available in a few years during childhood for some respondents (i.e. income rank requires weights during childhood to calculate). The numbers in parentheses are robust standard errors clustered by household. All Models include wave indicators (not shown).

$* * \mathrm{p}<.01, * \mathrm{p}<.05$ (two-tailed tests) 
Appendix C. Standardized and X-Standardized Coefficients from Alternative Linear Models Including Retrospective Social Class Measures for Six Health Outcomes at 40+.

\begin{tabular}{|c|c|c|c|c|c|c|}
\hline & $\begin{array}{l}\text { Self-Rated } \\
\text { Health }\end{array}$ & $\begin{array}{c}\text { Heart } \\
\text { Attack }\end{array}$ & Stroke & $\begin{array}{c}\text { Life-Threatening } \\
\text { Chronic }\end{array}$ & $\begin{array}{c}\text { Non-Life } \\
\text { Threatening } \\
\text { Chronic } \\
\end{array}$ & $\begin{array}{c}\text { Psychological } \\
\text { Distress }\end{array}$ \\
\hline Parent Income Rank & $\begin{array}{l}.099^{* *} \\
(.032)\end{array}$ & $\begin{array}{l}-.022^{*} \\
(.010)\end{array}$ & $\begin{array}{c}\text { able 1 Re } \\
-.021^{* *} \\
(.007)\end{array}$ & $\begin{array}{l}-.048^{* *} \\
(.016)\end{array}$ & $\begin{array}{l}.006 \\
(.016)\end{array}$ & $\begin{array}{l}-.085^{* *} \\
(.032)\end{array}$ \\
\hline $\begin{array}{l}\mathrm{N} \\
\text { Adjusted } \mathrm{R}^{2}\end{array}$ & $\begin{array}{c}3884 \\
.085 \\
\end{array}$ & $\begin{array}{c}3944 \\
.026 \\
\end{array}$ & $\begin{array}{c}3944 \\
.027 \\
\end{array}$ & $\begin{array}{r}3862 \\
.083 \\
\end{array}$ & $\begin{array}{l}3813 \\
.042 \\
\end{array}$ & $\begin{array}{c}3894 \\
.025 \\
\end{array}$ \\
\hline \multicolumn{7}{|c|}{ Include Prospective + Retrospective Father Education } \\
\hline Parent Income Rank & $\begin{array}{l}.113^{* *} \\
(.034)\end{array}$ & $\begin{array}{l}-.021 \\
(.011)\end{array}$ & $\begin{array}{l}-.017^{*} \\
(.007)\end{array}$ & $\begin{array}{c}-.059^{* *} \\
(.017)\end{array}$ & $\begin{array}{c}.004 \\
(.018)\end{array}$ & $\begin{array}{l}-.078^{*} \\
(.034)\end{array}$ \\
\hline Father H.S. Graduate & $\begin{array}{l}.230^{* *} \\
(.063)\end{array}$ & $\begin{array}{l}-.058^{*} \\
(.023)\end{array}$ & $\begin{array}{l}-.020 \\
(.016)\end{array}$ & $\begin{array}{l}-.047 \\
(.032)\end{array}$ & $\begin{array}{l}-.033 \\
(.032)\end{array}$ & $\begin{array}{l}-.172^{*} \\
(.071)\end{array}$ \\
\hline $\begin{array}{l}\text { Father College } \\
\text { Graduate }\end{array}$ & $\begin{array}{l}.264^{* *} \\
(.094)\end{array}$ & $\begin{array}{l}-.034 \\
(.031)\end{array}$ & $\begin{array}{l}.003 \\
(.024)\end{array}$ & $\begin{array}{l}-.047 \\
(.049)\end{array}$ & $\begin{array}{l}-.012 \\
(.048)\end{array}$ & $\begin{array}{l}-.129 \\
(.100)\end{array}$ \\
\hline $\begin{array}{l}\mathrm{N} \\
\text { Adjusted } \mathrm{R}^{2}\end{array}$ & $\begin{array}{c}3320 \\
.079\end{array}$ & $\begin{array}{c}3319 \\
.032\end{array}$ & $\begin{array}{c}3319 \\
.023\end{array}$ & $\begin{array}{c}3305 \\
.082\end{array}$ & $\begin{array}{l}3268 \\
.039\end{array}$ & $\begin{array}{c}3211 \\
.033\end{array}$ \\
\hline \multicolumn{7}{|c|}{ Include Only Retrospective Father Education } \\
\hline Father H.S. Graduate & $\begin{array}{l}.390^{* *} \\
(.057)\end{array}$ & $\begin{array}{c}-.077^{* *} \\
(.021)\end{array}$ & $\begin{array}{l}-.039^{* *} \\
(.014)\end{array}$ & $\begin{array}{l}-.102^{* *} \\
(.027)\end{array}$ & $\begin{array}{l}-.060^{*} \\
(.028)\end{array}$ & $\begin{array}{l}-.288^{* *} \\
(.064)\end{array}$ \\
\hline Father College & $.606^{* *}$ & $-.078^{* *}$ & $-.041^{*}$ & $-.166^{* *}$ & $-.070^{*}$ & $-.362^{* *}$ \\
\hline Graduate & $(.066)$ & $(.023)$ & $(.016)$ & $(.032)$ & $(.033)$ & $(.072)$ \\
\hline $\mathrm{N}$ & 3414 & 3413 & 3413 & 3399 & 3361 & 3305 \\
\hline Adjusted $\mathrm{R}^{2}$ & .067 & .027 & .016 & .074 & .036 & .030 \\
\hline \multicolumn{7}{|c|}{ Include Prospective + Retrospective Parent Subjective Economic Standing } \\
\hline Parent Income Rank & $\begin{array}{l}.098^{* *} \\
(.033)\end{array}$ & $\begin{array}{l}-.022^{*} \\
(.011)\end{array}$ & $\begin{array}{l}-.024^{* *} \\
(.008)\end{array}$ & $\begin{array}{l}-.046^{* *} \\
(.016)\end{array}$ & $\begin{array}{c}.004 \\
(.017)\end{array}$ & $\begin{array}{l}-.088^{* *} \\
(.033)\end{array}$ \\
\hline
\end{tabular}




\begin{tabular}{|c|c|c|c|c|c|c|}
\hline \multicolumn{7}{|l|}{$\begin{array}{l}\text { Appendix } C \\
\text { Continued... }\end{array}$} \\
\hline Parents Poor & $\begin{array}{l}-.098^{*} \\
(.050)\end{array}$ & $\begin{array}{l}.010 \\
(.017)\end{array}$ & $\begin{array}{l}.000 \\
(.012)\end{array}$ & $\begin{array}{l}.050^{*} \\
(.025)\end{array}$ & $\begin{array}{l}.046 \\
(.026)\end{array}$ & $\begin{array}{l}.040 \\
(.055)\end{array}$ \\
\hline Parents Well Off & $\begin{array}{l}-.091 \\
(.057)\end{array}$ & $\begin{array}{l}-.001 \\
(.017)\end{array}$ & $\begin{array}{l}.020 \\
(.012)\end{array}$ & $\begin{array}{l}.023 \\
(.027)\end{array}$ & $\begin{array}{l}.049 \\
(.027)\end{array}$ & $\begin{array}{l}.085 \\
(.056)\end{array}$ \\
\hline $\begin{array}{l}\mathrm{N} \\
\text { Adjusted } \mathrm{R}^{2}\end{array}$ & $\begin{array}{c}3786 \\
.088\end{array}$ & $\begin{array}{c}3839 \\
.024\end{array}$ & $\begin{array}{c}3839 \\
.029\end{array}$ & $\begin{array}{l}3765 \\
.086\end{array}$ & $\begin{array}{l}3720 \\
.044\end{array}$ & $\begin{array}{c}3809 \\
.027\end{array}$ \\
\hline \multicolumn{7}{|c|}{ Include Only Retrospective Parent Subjective Economic Standing } \\
\hline \multirow[b]{2}{*}{ Parents Well Off } & $\begin{array}{l}-.241^{* * *} \\
(.050)\end{array}$ & $\begin{array}{l}.033^{*} \\
(.016)\end{array}$ & $\begin{array}{l}.016 \\
(.011)\end{array}$ & $\begin{array}{l}.088^{* *} \\
(.024)\end{array}$ & $\begin{array}{l}.061^{*} \\
(.025)\end{array}$ & $\begin{array}{l}.133^{*} \\
(.054)\end{array}$ \\
\hline & $\begin{array}{l}-.046 \\
(.057)\end{array}$ & $\begin{array}{l}-.006 \\
(.016)\end{array}$ & $\begin{array}{l}.017 \\
(.012)\end{array}$ & $\begin{array}{l}.009 \\
(.027)\end{array}$ & $\begin{array}{l}.045 \\
(.027)\end{array}$ & $\begin{array}{l}.055 \\
(.056)\end{array}$ \\
\hline $\mathrm{N}$ & 3894 & 3951 & 3951 & 3873 & 3827 & 3939 \\
\hline Adjusted $\mathrm{R}^{2}$ & .040 & .017 & .018 & .073 & .040 & .010 \\
\hline \multicolumn{7}{|c|}{ Table 1 Results with No Missing on Father's Education } \\
\hline Parent Income Rank & $\begin{array}{l}.121^{* *} \\
(.034)\end{array}$ & $\begin{array}{l}-.023^{*} \\
(.011)\end{array}$ & $\begin{array}{l}-.018^{*} \\
(.007)\end{array}$ & $\begin{array}{c}-.061^{* *} \\
(.017)\end{array}$ & $\begin{array}{l}.003 \\
(.018)\end{array}$ & $\begin{array}{l}-.085^{*} \\
(.034)\end{array}$ \\
\hline $\mathrm{N}$ & 3320 & 3319 & 3319 & 3305 & 3268 & 3211 \\
\hline Adjusted $\mathrm{R}^{2}$ & .074 & .027 & .021 & .081 & .039 & .029 \\
\hline \multicolumn{7}{|c|}{ Table 1 Results with No Missing on Retrospective Parent Subjective Economic Standing } \\
\hline Parent Income Rank & $\begin{array}{l}.105^{* *} \\
(.033)\end{array}$ & $\begin{array}{l}-.024^{*} \\
(.011)\end{array}$ & $\begin{array}{l}-.023^{* *} \\
(.007)\end{array}$ & $\begin{array}{c}-.051^{* *} \\
(.016)\end{array}$ & $\begin{array}{l}.002 \\
(.017)\end{array}$ & $\begin{array}{l}-.088^{* *} \\
(.033)\end{array}$ \\
\hline $\mathrm{N}$ & 3786 & 3839 & 3839 & 3765 & 3720 & 3809 \\
\hline Adjusted $\mathrm{R}^{2}$ & .086 & .025 & .028 & .085 & .042 & .026 \\
\hline
\end{tabular}

The numbers in parentheses are robust standard errors clustered by household. All Models include wave indicators (not shown). $* * \mathrm{p}<.01, * \mathrm{p}<.05$ (two-tailed tests) 
Appendix D. Standardized and X-Standardized Coefficients from Alternative Linear Models Only Including Respondents Aged 50+ for Six Health Outcomes.

\begin{tabular}{|c|c|c|c|c|c|}
\hline Self-Rated Health & Heart Attack & Stroke & $\begin{array}{c}\text { Life-Threatening } \\
\text { Chronic }\end{array}$ & $\begin{array}{c}\text { Non-Life- } \\
\text { Threatening } \\
\text { Chronic }\end{array}$ & $\begin{array}{c}\text { Psychological } \\
\text { Distress }\end{array}$ \\
\hline $\begin{array}{l}.099^{* *} \\
(.032)\end{array}$ & $\begin{array}{l}-.022^{*} \\
(.010)\end{array}$ & $\begin{array}{c}\text { ble } 1 \text { Res } \\
-.021^{* *} \\
(.007)\end{array}$ & $\begin{array}{l}-.048^{* *} \\
(.016)\end{array}$ & $\begin{array}{c}.006 \\
(.016)\end{array}$ & $\begin{array}{l}-.085^{* *} \\
(.032)\end{array}$ \\
\hline $\begin{array}{c}3884 \\
.085\end{array}$ & $\begin{array}{c}3944 \\
.026\end{array}$ & $\begin{array}{c}3944 \\
.027\end{array}$ & $\begin{array}{c}3862 \\
.083\end{array}$ & $\begin{array}{l}3813 \\
.042\end{array}$ & $\begin{array}{l}3894 \\
.025\end{array}$ \\
\hline $\begin{array}{c}.054 \\
(.041)\end{array}$ & $\begin{array}{l}{ }^{\text {Resp }} \\
-.030^{*} \\
(.014)\end{array}$ & $\begin{array}{c}\text { ndents } \boldsymbol{A g} \\
-.032^{* *} \\
(.011)\end{array}$ & $\begin{array}{l}-.044^{*} \\
(.021)\end{array}$ & $\begin{array}{c}.014 \\
(.021)\end{array}$ & $\begin{array}{l}-.024 \\
(.044)\end{array}$ \\
\hline $\begin{array}{c}2150 \\
.079 \\
\end{array}$ & $\begin{array}{l}2195 \\
.023 \\
\end{array}$ & $\begin{array}{r}2195 \\
.027 \\
\end{array}$ & $\begin{array}{r}2147 \\
.057 \\
\end{array}$ & $\begin{array}{c}2148 \\
.041 \\
\end{array}$ & $\begin{array}{c}2186 \\
.018 \\
\end{array}$ \\
\hline
\end{tabular}

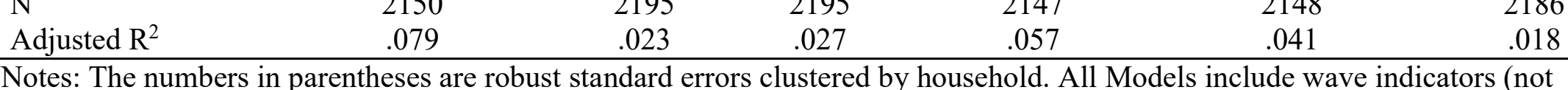
shown).

$* * \mathrm{p}<.01, * \mathrm{p}<.05$ (two-tailed tests) 
Appendix E. Standardized and X-Standardized Coefficients from Alternative Linear Models Only Including Respondents Aged 30+ for Six Health Outcomes.

\begin{tabular}{|c|c|c|c|c|c|}
\hline Self-Rated Health & Heart Attack & Stroke & $\begin{array}{c}\text { Life-Threatening } \\
\text { Chronic }\end{array}$ & $\begin{array}{c}\text { Non-Life- } \\
\text { Threatening } \\
\text { Chronic }\end{array}$ & $\begin{array}{l}\text { Psychological } \\
\text { Distress }\end{array}$ \\
\hline $\begin{array}{l}.099^{* *} \\
(.032)\end{array}$ & $\begin{array}{l}-.022^{*} \\
(.010)\end{array}$ & $\begin{array}{c}\text { ble } 1 \text { Res } \\
-.021^{* *} \\
(.007)\end{array}$ & $\begin{array}{l}-.048^{* *} \\
(.016)\end{array}$ & $\begin{array}{c}.006 \\
(.016)\end{array}$ & $\begin{array}{l}-.085^{* *} \\
(.032)\end{array}$ \\
\hline $\begin{array}{c}3884 \\
.085 \\
\end{array}$ & $\begin{array}{c}3944 \\
.026 \\
\end{array}$ & $\begin{array}{c}3944 \\
.027 \\
\end{array}$ & $\begin{array}{c}3862 \\
.083 \\
\end{array}$ & $\begin{array}{c}3813 \\
.042 \\
\end{array}$ & $\begin{array}{c}3894 \\
.025 \\
\end{array}$ \\
\hline $\begin{array}{l}.078^{* *} \\
(.027)\end{array}$ & $\begin{array}{l}{ }^{\text {Resp }} \\
-.014 \\
(.007)\end{array}$ & $\begin{array}{c}\text { ndents } A \mathrm{~g} \\
-.015^{* *} \\
(.005)\end{array}$ & $\begin{array}{ll}30+ & \\
& -.033^{* *} \\
& (.013)\end{array}$ & $\begin{array}{l}-.002 \\
(.013)\end{array}$ & $\begin{array}{l}-.065^{*} \\
(.027)\end{array}$ \\
\hline $\begin{array}{l}6395 \\
.088\end{array}$ & $\begin{array}{c}6479 \\
.039\end{array}$ & $\begin{array}{c}6479 \\
.029\end{array}$ & $\begin{array}{l}6332 \\
.122\end{array}$ & $\begin{array}{l}6220 \\
.061\end{array}$ & $\begin{array}{r}6541 \\
.019\end{array}$ \\
\hline
\end{tabular}

\begin{tabular}{lccccc}
$\mathrm{N}$ & 6395 & 6479 & 6479 & 6332 & .122 \\
Adjusted $\mathrm{R}^{2}$ & .088 & .039 & .029 & .061 & .019 \\
\hline Notes: The numbers in parentheses are robust standard errors clustered by household. All Models include wave indicators (not
\end{tabular}
shown).

${ }^{* *} \mathrm{p}<.01,{ }^{*} \mathrm{p}<.05$ (two-tailed tests) 
Appendix F. Standardized and X-Standardized Coefficients from Alternative Linear Models Including ONLY Heads of Households for Six Health Outcomes at 40+.

$\begin{array}{lllll}\text { Self-Rated Health Heart Attack } & \text { Stroke } & \begin{array}{c}\text { Life- } \\ \text { Threatening } \\ \text { Chronic }\end{array} & \begin{array}{c}\text { Non-Life- } \\ \text { Threatening }\end{array} & \text { Psychological Distress }\end{array}$

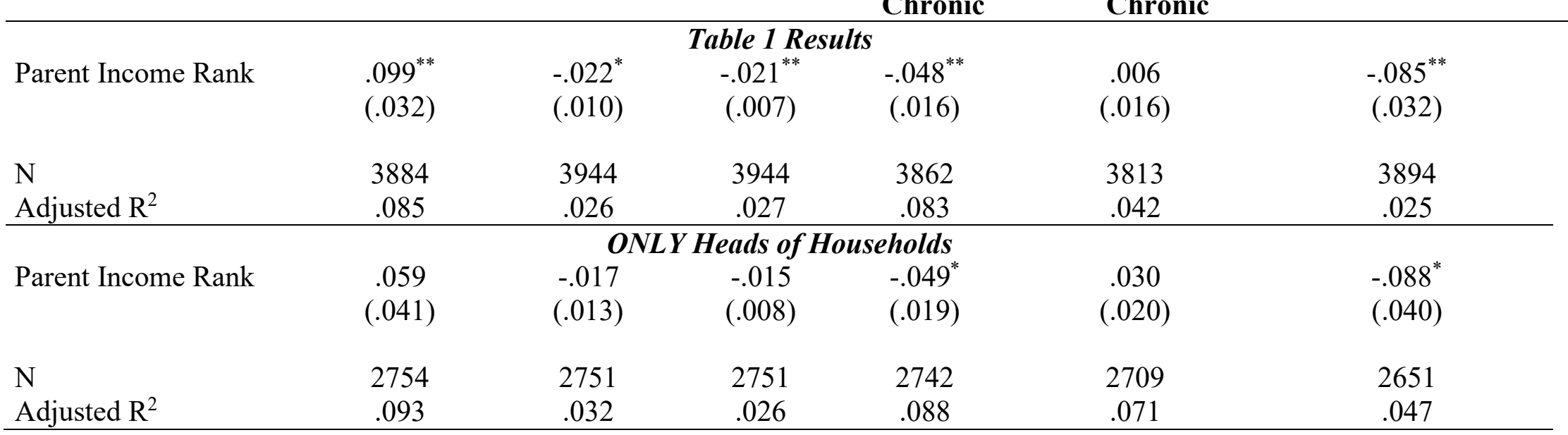

The numbers in parentheses are robust standard errors clustered by household. All Models include wave indicators (not shown). $* * \mathrm{p}<.01, * \mathrm{p}<.05$ (two-tailed tests) 
Appendix G. Standardized and X-Standardized Coefficients from Alternative Linear Models Including Logged Parent Income Rank and Education for Six Health Outcomes at 40+.

\begin{tabular}{|c|c|c|c|c|c|c|}
\hline & $\begin{array}{l}\text { Self-Rated } \\
\text { Health }\end{array}$ & Heart Attack & Stroke & $\begin{array}{c}\text { Life- } \\
\text { Threatening } \\
\text { Chronic }\end{array}$ & $\begin{array}{c}\text { Non-Life- } \\
\text { Threatening } \\
\text { Chronic }\end{array}$ & $\begin{array}{c}\text { Psychological } \\
\text { Distress }\end{array}$ \\
\hline Parent Income Rank & $\begin{array}{l}.099^{* *} \\
(.032)\end{array}$ & $\begin{array}{l}-.022^{*} \\
(.010)\end{array}$ & $\begin{array}{l}1 \text { Results } \\
-.021^{* *} \\
(.007)\end{array}$ & $\begin{array}{l}-.048^{* *} \\
(.016)\end{array}$ & $\begin{array}{l}.006 \\
(.016)\end{array}$ & $\begin{array}{l}-.085^{* *} \\
(.032)\end{array}$ \\
\hline $\begin{array}{l}\mathrm{N} \\
\text { Adjusted } \mathrm{R}^{2}\end{array}$ & $\begin{array}{c}3884 \\
.085 \\
\end{array}$ & $\begin{array}{l}3944 \\
.026 \\
\end{array}$ & $\begin{array}{l}3944 \\
.027 \\
\end{array}$ & $\begin{array}{c}3862 \\
.083 \\
\end{array}$ & $\begin{array}{c}3813 \\
.042 \\
\end{array}$ & $\begin{array}{c}3894 \\
.025\end{array}$ \\
\hline $\begin{array}{l}\text { Log Parent Income } \\
\text { Rank }\end{array}$ & $\begin{array}{l}.098^{* *} \\
(.032)\end{array}$ & \begin{tabular}{l}
\multicolumn{1}{c}{$\log 1$} \\
-.015 \\
$(.010)$
\end{tabular} & $\begin{array}{c}\text { asformatio } \\
-.015^{*} \\
(.007)\end{array}$ & $\begin{array}{l}-.043^{* * *} \\
(.015)\end{array}$ & $\begin{array}{l}.005 \\
(.015)\end{array}$ & $\begin{array}{l}-.085^{* *} \\
(.032)\end{array}$ \\
\hline $\begin{array}{l}\mathrm{N} \\
\text { Adjusted } \mathrm{R}^{2}\end{array}$ & $\begin{array}{c}3884 \\
.085 \\
\end{array}$ & $\begin{array}{c}3944 \\
.025 \\
\end{array}$ & $\begin{array}{c}3944 \\
.025 \\
\end{array}$ & $\begin{array}{c}3862 \\
.083 \\
\end{array}$ & $\begin{array}{c}3813 \\
.042 \\
\end{array}$ & $\begin{array}{c}3894 \\
.025 \\
\end{array}$ \\
\hline $\begin{array}{l}\text { Log Parent Absolute } \\
\text { Income }\end{array}$ & $\begin{array}{l}.115^{* *} \\
(.031)\end{array}$ & $\begin{array}{l}-.021^{*} \\
(.010)\end{array}$ & $\begin{array}{l}-.018^{* *} \\
(.007)\end{array}$ & $\begin{array}{c}-.045^{* *} \\
(.015)\end{array}$ & $\begin{array}{l}.011 \\
(.016)\end{array}$ & $\begin{array}{c}-.087^{* *} \\
(.031)\end{array}$ \\
\hline $\begin{array}{l}\mathrm{N} \\
\text { Adjusted } \mathrm{R}^{2}\end{array}$ & $\begin{array}{c}3996 \\
.087 \\
\end{array}$ & $\begin{array}{r}4061 \\
.026\end{array}$ & $\begin{array}{r}4061 \\
.026 \\
\end{array}$ & $\begin{array}{c}3974 \\
.083\end{array}$ & $\begin{array}{c}3924 \\
.042\end{array}$ & $\begin{array}{c}4029 \\
.028 \\
\end{array}$ \\
\hline
\end{tabular}

The numbers in parentheses are robust standard errors clustered by household. All Models include wave indicators (not shown). $* * \mathrm{p}<.01, * \mathrm{p}<.05$ (two-tailed tests) 
Appendix H. Unstandardized Coefficients from Alternative Linear Models Including Polynomial Functions for Parent Income Rank and Education for Six Health Outcomes at 40+.

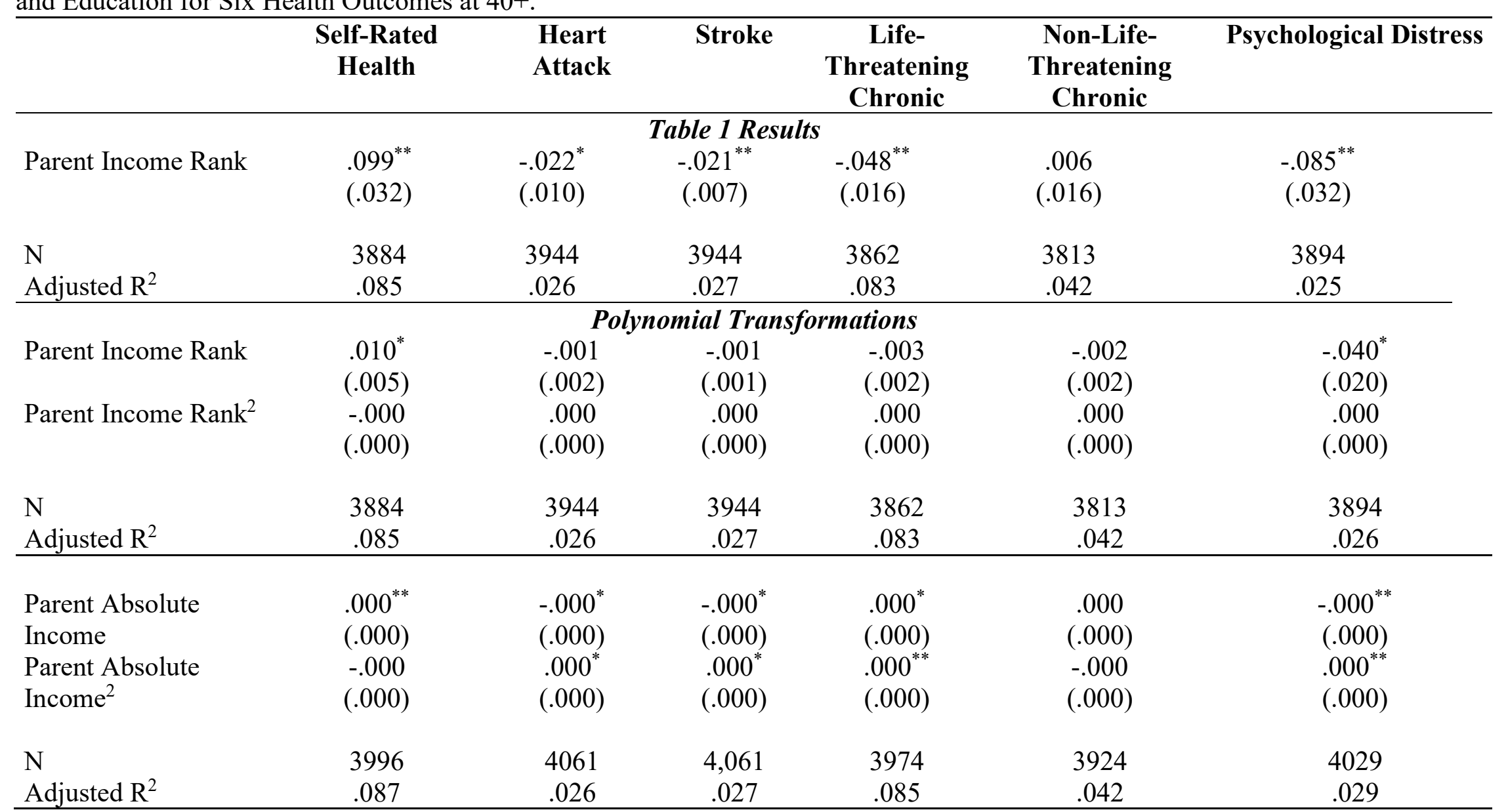

The numbers in parentheses are robust standard errors clustered by household. All Models include wave indicators (not shown).

$* * \mathrm{p}<.01, * \mathrm{p}<.05$ (two-tailed tests) 
Appendix I. Standardized and X-Standardized Coefficients from Alternative Linear Models Using a Common Sample Size With Zero Missing for All Six Health Outcomes at 40+.

\begin{tabular}{|c|c|c|c|c|c|c|}
\hline & $\begin{array}{c}\text { Self-Rated } \\
\text { Health }\end{array}$ & Heart Attack & Stroke & $\begin{array}{c}\text { Life- } \\
\text { Threatening } \\
\text { Chronic }\end{array}$ & $\begin{array}{c}\text { Non-Life- } \\
\text { Threatening } \\
\text { Chronic }\end{array}$ & $\begin{array}{c}\text { Psychological } \\
\text { Distress }\end{array}$ \\
\hline \multicolumn{7}{|c|}{ Table 1 Results } \\
\hline Parent Income Rank & $.099^{* *}$ & $-.022^{*}$ & $-.021^{* *}$ & $-.048^{* *}$ & .006 & $-.085^{* *}$ \\
\hline & $(.032)$ & $(.010)$ & $(.007)$ & $(.016)$ & $(.016)$ & $(.032)$ \\
\hline $\mathrm{N}$ & 3884 & 3944 & 3944 & 3862 & 3813 & 3894 \\
\hline Adjusted $\mathrm{R}^{2}$ & .085 & .026 & .027 & .083 & .042 & .025 \\
\hline \multicolumn{7}{|c|}{ Common Sample Size } \\
\hline Parent Income Rank & $.110^{* *}$ & $-.027^{* *}$ & $-.020^{* *}$ & $-.051^{* *}$ & .002 & $-.078^{*}$ \\
\hline & $(.032)$ & $(.010)$ & & $(.016)$ & $(.016)$ & $(.031)$ \\
\hline $\mathrm{N}$ & 3702 & 3702 & 3702 & 3702 & 3702 & 3702 \\
\hline Adjusted $\mathrm{R}^{2}$ & .088 & .029 & .027 & .085 & .039 & .026 \\
\hline
\end{tabular}

The numbers in parentheses are robust standard errors clustered by household. All Models include wave indicators (not shown). $* * \mathrm{p}<.01, * \mathrm{p}<.05$ (two-tailed tests) 
Appendix J. Analyses of Different Childhood Stages.

Panel A. Correlation Matrix for Various Measures of Parent Income Rank Averages Across Childhood Stages: Pearson's R and N.

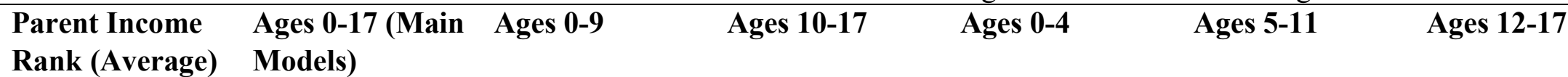

\begin{tabular}{|c|c|c|c|c|c|c|}
\hline $\begin{array}{l}\text { Ages 0-17 (Main } \\
\text { Models) }\end{array}$ & 1.00 & & & & & \\
\hline Ages 0-9 & .95 & 1.00 & & & & \\
\hline Ages 10-17 & .98 & .84 & 1.00 & & & \\
\hline Ages 0-4 & .87 & .93 & .73 & 1.00 & & \\
\hline Ages 5-11 & .96 & .96 & .91 & .82 & 1.00 & \\
\hline Ages $12-17$ & .97 & .81 & .99 & .70 & .87 & 1.00 \\
\hline
\end{tabular}

Panel B. Standardized and X-Standardized Coefficients from Alternative Linear Models Using a Common Sample Size With Zero Missing for All Six Health Outcomes at 40+.

\begin{tabular}{|c|c|c|c|c|c|c|}
\hline & $\begin{array}{l}\text { Self-Rated } \\
\text { Health }\end{array}$ & Heart Attack & Stroke & $\begin{array}{c}\text { Life- } \\
\text { Threatening } \\
\text { Chronic }\end{array}$ & $\begin{array}{c}\text { Non-Life- } \\
\text { Threatening } \\
\text { Chronic }\end{array}$ & $\begin{array}{c}\text { Psychological } \\
\text { Distress }\end{array}$ \\
\hline \multicolumn{7}{|c|}{ Ages 0-9 \& 10-17 } \\
\hline Parent Income Rank & -.014 & -.019 & .002 & -.021 & .010 & .048 \\
\hline Ages $0-9$ & $(.045)$ & $(.012)$ & $(.008)$ & $(.023)$ & $(.023)$ & $(.191)$ \\
\hline Parent Income Rank & $.122^{* *}$ & -.000 & $-.017^{*}$ & -.047 & -.003 & $-.479^{*}$ \\
\hline Ages $10-17$ & $(.047)$ & $(.014)$ & $(.008)$ & $(.024)$ & $(.024)$ & $(.213)$ \\
\hline $\mathrm{N}$ & 2550 & 2606 & 2606 & 2546 & 2536 & 2637 \\
\hline Adjusted $\mathrm{R}^{2}$ & .083 & .025 & .020 & .058 & .026 & .031 \\
\hline
\end{tabular}




\begin{tabular}{|c|c|c|c|c|c|c|}
\hline \multicolumn{7}{|c|}{ Ages 0-4, 5-11 \& 12-17 } \\
\hline Parent Income Rank & .016 & .000 & -.006 & -.007 & .046 & .337 \\
\hline Ages $0-4$ & $(.052)$ & $(.014)$ & $(.008)$ & $(.025)$ & $(.025)$ & $(.213)$ \\
\hline Parent Income Rank & .062 & -.011 & .005 & -.039 & -.043 & $-.782^{*}$ \\
\hline Ages 5-11 & $(.072)$ & $(.019)$ & $(.012)$ & $(.035)$ & $(.036)$ & $(.312)$ \\
\hline Parent Income Rank & $.121^{*}$ & -.000 & -.017 & -.042 & .009 & -.294 \\
\hline Ages $12-17$ & $(.061)$ & $(.016)$ & $(.011)$ & $(.030)$ & $(.031)$ & $(.291)$ \\
\hline $\mathrm{N}$ & 1727 & 1763 & 1763 & 1725 & 1726 & 1804 \\
\hline Adjusted $\mathrm{R}^{2}$ & .085 & .016 & .015 & .046 & .028 & .041 \\
\hline
\end{tabular}

The numbers in parentheses are robust standard errors clustered by household. All Models include wave indicators (not shown). $* * \mathrm{p}<.01, * \mathrm{p}<.05$ (two-tailed tests) 